\title{
New insights on the Early Pleistocene equids from Roca-Neyra (France, central Europe): implications for the Hipparion LAD and the Equus FAD in Europe
}

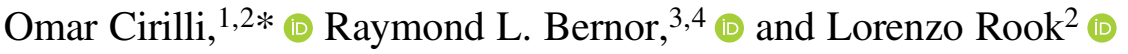 \\ ${ }^{1}$ Dottorato di Ricerca in Scienze della Terra, Università di Pisa, Via S. Maria 53, 56126 Pisa, Italy <omar.cirilli@phd.unipi.it> \\ ${ }^{2}$ Dipartimento di Scienze della Terra, Paleo[Fab]Lab, Università degli Studi di Firenze, Via G. La Pira 4, 50121 Firenze, Italy <lorenzo. \\ rook@unifi.it> \\ ${ }^{3}$ College of Medicine, Department of Anatomy, Laboratory of Evolutionary Biology, 520 W St. N.W., 20059, Washington D.C., USA \\ <rbernor@Howard.edu> \\ ${ }^{4}$ Human Origins Program, Department of Anthropology, Smithsonian Institution, 20560, Washington D.C., USA
}

\begin{abstract}
We undertake a redescription of the equid sample from the Early Pleistocene of Roca-Neyra, France. This locality has been recently calibrated at the Pliocene/Pleistocene boundary $(2.6 \pm 0.2 \mathrm{Ma})$ and therefore it is of interest for the first appearance of the genus Equus and last appearance of hipparionine horses. The Roca-Neyra equid sample, reanalyzed herein using morphological, morphometrical, and statistical analyses, has revealed the co-occurrence of Plesiohipparion cf. ?P. rocinantis and Equus cf. E. livenzovensis. The analysis undertaken on several European, African, and Asian "Hipparion" sensu lato species from late Miocene to Early Pleistocene has revealed different remnant Hipparion lineages in the Plio-Pleistocene of Europe: Plesiohipparion, Proboscidippaion, and likely Cremohipparion. The discovery of the first European monodactyl horse, Equus cf. E. livenzovensis correlates Roca-Neyra with other 2.6 Ma European localities in Italy, Spain, and in the Khapry area (Azov Sea region). The morphological description of the Equus cf. E. livenzovensis lower cheek teeth has highlighted intermediate features between the North American Pliocene species Equus simplicidens and Early Pleistocene European Equus stenonis. Our study supports the hypothesis that E. livenzovensis is a plausible evolutionary predecessor for the Equus stenonis group. These observations underscore the importance of Roca-Neyra as an important locality for the last European hipparions and the first Equus in the Early Pleistocene of Europe.
\end{abstract}

\section{Introduction}

Roca-Neyra is an important Early Pleistocene locality located within the Perrier Plateau area, France (Fig. 1). The Perrier Plateau area contains a continental fluvial sequence and, due to the proximity of the Mont-Dore stratovolcano, includes several volcanic ash and pumice layers interbedded within the sedimentary sequence (Pastre, 2004; Nomade et al., 2014). Its geological record spans the late Pliocene to the Early Pleistocene and has provided an important fossil assemblage since its initial discovery in the second half of the $19^{\text {th }}$ century. Within the context of their review of late Pliocene and Early Pleistocene sites of France, Nomade et al. (2014) have reassessed the chronological calibration for the most important localities included in the Perrier Plateau area, Les Etouaires, Roca-Neyra, La Loubière de Pardines, and Le Creux de Peyrolles, chronologically constrained by ${ }^{40} \mathrm{Ar} /{ }^{39} \mathrm{Ar}$ analysis. Roca-Neyra's age has been calibrated as being $2.6 \pm 0.2 \mathrm{Ma}$ (Nomade et al., 2014) and correlates with the Italian Early Pleistocene locality of Montopoli (lower Valdarno basin, Italy; Rook et al., 2017). Together

*Corresponding Author these two localities mark the lowermost limit of the Pleistocene at the Gauss/Matuyama polarity transition and in turn correlate to the lower limit of Mammal Zone MNQ 16b of the European Land Mammal Age biochronologic scheme (Guérin, 1990; Mein, 1999).

As reported above, four main fossiliferous localities have been identified in the Perrier plateau area: Les-Etouaires (2.77 $\pm 0.02 \mathrm{Ma}$ ), Roca-Neyra (2.6 $\pm 0.2 \mathrm{Ma})$, La Loubière de Pardines (slightly younger than Roca-Neyra but older than Saint Vallier) and Le Creux de Peyrolles $(1.49 \pm 0.01 \mathrm{Ma})$, (Nomade et al., 2014). The locality of Roca-Neyra was discovered in 1872-1873. Site excavations were led at the end of the $19^{\text {th }}$ and at the beginning of the $20^{\text {th }}$ century, and the collection housed in the Natural History Museum of Basel, at the Faculté des Sciences de Clermont and at the Université Claude Bernard-1, Lyon. The fossiliferous levels are considered penecontemporaneous with the debris avalanches that fossilized the sedimentary sequence of the Perrier Plateau (Nomade et al., 2014) and the Roca-Neyra fossil locality is constrained within the first two debris avalanches of the Perrier Plateau area. The Roca-Neyra equid assemblage was previously reported by Stehlin (1904), who highlighted the presence of an "Hipparion" (not demonstrably of the genus Hipparion s.s., Woodburne and 


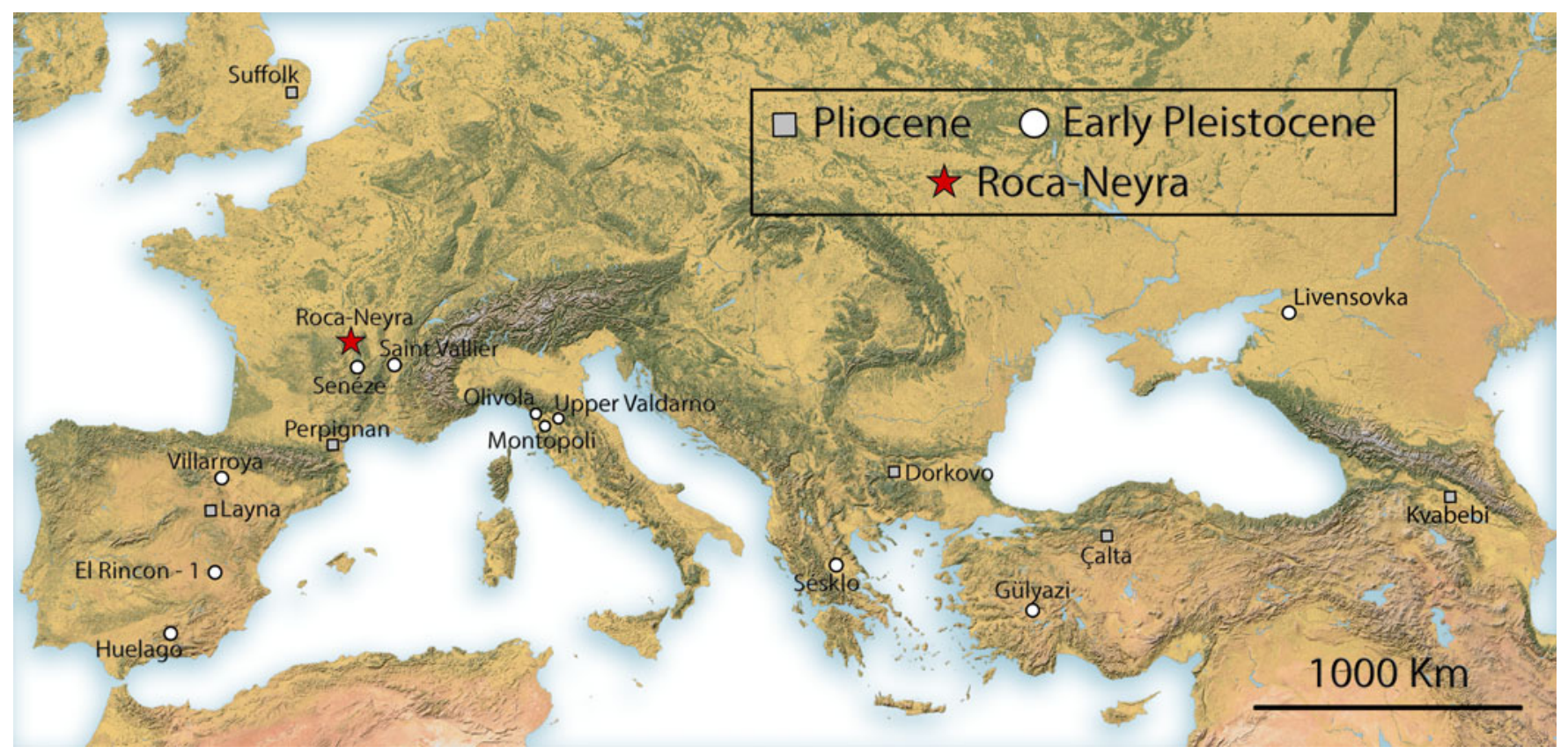

Figure 1. Geographical map showing the locality of Roca-Neyra with the European Plio-Pleistocene localities mentioned in the text. Base map from QGis (https:// qgis.org/).

Bernor, 1980; Bernor et al., 1996, 2016) in the faunal assemblage. Later, the equid assemblage was discussed by several authors, many of whom challenged the presence of "Hipparion" and Equus (Schaub, 1944; Bout, 1960; Kurten, 1963; Radulescu and Samson, 1967). Finally, the co-occurrence of both genera has been clarified by Eisenmann and Brunet (1973), who confirmed the occurrence of "Hipparion" sp. and Equus cf. E. stenonis. The faunal assemblage of Roca-Neyra is consistent with the local stratigraphy and includes the following faunal assemblage: Nyctereutes megamastoide Pomel, 1842, Chasmaporthetes lunensis Del Campana, 1914, Lynx issiodorensis Croizet and Jobert, 1828, Anancus cf. A. arvernensis Croizet and Jobert, 1828, "Hipparion" rocinantis Hernández-Pacheco, 1921, Equus stenonis Cocchi, 1867, Eucladoceros ctenoides vireti Heintz, 1970, Leptobos elatus Pomel, 1853, Gazellospira torticornis Aymard, 1854, ?Procamptoceras brivatense Schaub, 1923, and Gazella borbonica Depéret, 1884 (see Palombo and Valli, 2004).

The base of the Pleistocene is an event marked by the global environmental change from warm-humid ecosystems to coolarid conditions. In the fossil record, this event is documented by the inter-continental dispersal of the genus Equus (Lindsay et al., 1980; Azzaroli, 1983; Bernor et al., 2019; Rook et al., 2019). In the Mediterranean region, this faunal turnover is recorded in the Early Pleistocene (MNQ16b) sites of Montopoli (Italy) and El Rincón-1 (Spain), where the occurrence of the large stenonine horse Equus livenzovensis Bajgusheva, 1978 is reported (Alberdi et al., 1997; Azzaroli, 2000; Bernor et al., 2018b). In Eastern Europe, the Equus event is documented by the occurrence of Equus livenzovensis at Khapry (Azov Sea area, Russia) and Livensovka (Rostov, Russia) localities (Bajgusheva, 1978; Azzaroli, 2000; Bernor et al., 2018b; Bernor et al., 2019). In Western-Central Europe, this biochronologic event is represented by the locality of Roca-Neyra, where the occurrence of the genus Equus is associated with the three-toed horse "Hipparion." The species reported in the literature are Equus cf. E. stenonis and "Hipparion" rocinantis (Stehlin, 1904; Eisenmann and Brunet, 1973; Palombo and Valli, 2004).

Here, we revise, describe, and analyze the Roca-Neyra equid sample housed in the Universite Claude Bernard-1 in Lyon, with new considerations on the last occurrence of the European "Hipparion" lineages and the Equus dispersal event.

\section{Materials and methods}

Part of the Roca-Neyra equid sample is housed in the paleontological collection at the Université Claude Bernard-1 in Lyon, and it is represented by a right calcaneum (UCBL-FSL 211232), a second phalanx of the central digit (UCBL-FSL 211733), a third phalanx of the central digit (UCBL-FSL 211733) of "Hipparion," and three isolated teeth, probably belonging to the same individual (left p4, m1, and m2; UCBL-FSL 211735) of Equus. Moreover, Eisenmann and Brunet (1973) reported two "Hipparion" third metatarsals from Roca-Neyra (MNHN 1948-13-11, and NHMB RN 98; table 2, p. 114). Stehlin (1904) preliminarily reported the Roca-Neyra collection housed at the Facultés des Science de Clermont, but unfortunately no data or additional information on this collection have been reported since 1904.

We review the Roca-Neyra equid sample housed in the paleontological collection at the Université Claude Bernard-1, Lyon and compare it to a suite of European, African, and Asian Miocene, Pliocene, and Pleistocene "Hipparion" species, with the North America and Eurasian Plio-Pleistocene Equus species, and with extant Equus grevyi Oustalet, 1882. The late Miocene-Early Pleistocene "Hipparion" species included in our analyses are: Hippotherium primigenium von Meyer, 1829 (Höwenegg, Germany; data from Bernor et al., 1997), 
"Cormohipparion" africanum Arambourg, 1959 (Bou Hanifia, Algeria; data from Bernor and White, 2009), Cormohipparion sinapensis Bernor et al. in Fortelius et al., 2003 (Sinap, Turkey; data from Bernor et al., 2003), Eurygnathohippus feibeli Bernor and Harris, 2003 (Sahabi, Libya; data from Bernor et al., 2012, 2020), Sivalhippus turkanensis Hooijer and Maglio, 1974 (Lothagam, Kenya; data from Bernor and Harris, 2003), Sivalhippus perimensis Pilgrim, 1910 (Siwalik, Pakistan; data from Wolf et al., 2013), Cremohipparion mediterraneum Roth and Wagner, 1855 (Pikermi, Greece; data from Koufos, 1986), Cremohipparion matthewi Abel, 1926 (Samos, Greece; data from Bernor et al., 1996), Plesiohipparion longipes Gromova, 1952 (Pavlodar, Kazakhstan; data from Eisenmann, 2019, https:// vera-eisenmann.com), "Hipparion" elegans Gromova, 1952 (Pavlodar, Kazakhstan; data from Eisenmann, 2019, https:// vera-eisenmann.com), Plesiohipparion longipes (Akkaşdağ 1 and Çalta, Turkey; data from Koufos and Vlachou, 2005), Plesiohipparion houfenense Teilhard de Chardin and Young, 1931 (Houfeng, China; Qiu et al., 1987; data from Bernor et al., 2015), Plesiohipparion rocinantis Hernández-Pacheco, 1921 (Villarroya, Spain; Zhegallo, 1978; Pueyo et al., 2016; Rook et al., 2017; data from Eisenmann, 2019, https://veraeisenmann.com), Proboscidipparion heintzi Eisenmann and Sondaar, 1998 (Çalta, Turkey; Eisenmann and Sondaar, 1998; data from Bernor and Sen, 2017), "Hipparion" fissurae Crusafont and Sondaar, 1971 (Layna, Spain; data from Alberdi and Alcalà, 1999), "Hipparion" crassum Gervais, 1859 (Perpignan, France; data from Eisenmann, 2019, https://vera-eisenmann. com) and "Hipparion" rocinantis from the Georgian locality of Kvabebi (Vekua, 1972; data from Eisenmann, 2019, https:// vera-eisenmann.com). We utilize this broad range of "Hipparion" lineages in order to isolate those "Hipparion" lineages to be the most likely source of the Roca-Neyra "Hipparion" species.

The Pliocene and Pleistocene Equus species considered are: Equus simplicidens Cope, 1892 (Hagerman Horse Quarry, Idaho; authors' unpublished data), Equus stenonis vireti Prat, 1964 (Saint Vallier, France; authors' unpublished data), Equus sp. (Senèze; authors' unpublished data), Equus stenonis Cocchi, 1867 (from both Olivola and Upper Valdarno Basin, Italy; authors' unpublished data) Equus stehlini Azzaroli, 1964 (Upper Valdarno Basin, Italy; authors' unpublished data), Equus suessenbornensis Wüst, 1900 (Süssenborn, Germany; authors' unpublished data) and Equus grevyi (Kenya, Africa; authors' unpublished data). The Equus sample from the Early Pleistocene of Senèze is here retained at the genus level (Equus sp.), due to the conflicting opinions about which and how many species are in the fossil locality (for a comprehensive review see Alberdi et al., 1998; Delson et al., 2006; Palombo and Alberdi, 2017; Palombo et al., 2017; and Eisenmann, 2019).

Anatomical nomenclature and osteological landmarks are according to Bernor et al. (1997). Morphometric measurements follow Eisenmann et al. (1988) and Bernor et al. (1997). We undertake morphometric and statistical analyses using bivariate plots, Log10 ratio diagrams (Höwenegg Hippotherium primigenium means used as the $\log 10$ standards; Bernor et al., 1997) and Principal Components Analysis (PCA).

Eisenmann (1995), Bernor and Harris (2003), Bernor et al. (2003, 2005, 2016, 2018a, b, 2019), Bernor and Sen (2017), Sun et al. (2018), and Cirilli et al. (2020, in press) have used Log 10 ratio diagrams on postcranial elements to evaluate differences between selected species of "Hipparion" and Equus species and their evolutionary trends. We follow these authors in our analyses of third metapodials and for lower dentitions in the Equus sample. Furthermore, we have extended the statistical analyses also using PCA, using R software through the function prcomp() (R Core Team, 2013).

"Hipparion" bivariate plots have been selected for the following anatomical elements (including the following measurements): third metacarpal and metatarsal (M1 = maximal length; M11 = distal maximal articular width), second phalanx of the central digit ( $11=$ maximal length; $\mathrm{M} 6=$ distal maximal width). "Hipparion" third metacarpal and third metatarsal Log10 ratio diagrams include $\mathrm{M} 1=$ maximum length; $\mathrm{M} 3=$ minimal width; M4 = depth of the diaphysis at level of M3; M5 = proximal articular breadth; M6 = proximal articular width; M7 = maximal diameter of the articular facet for the third carpal/tarsal; M8 = diameter for the anterior facet for the fourth carpal/tarsal; M10 = distal maximal supra articular width; M11 = distal maximal articular width; M12=distal maximal keel depth; M13 = distal maximal depth of the lateral condyle; M14 = distal maximal depth of the medial condyle. "Hipparion" third metacarpal and metatarsal PCAs include the following measurements: M1, M3, M4, M5, M6, M10, M11, M12, M13, M14 (same measurements used in $\log 10$ ratio diagrams).

Equus mandibular cheek tooth (tmp4-tmm2) bivariate plots include M1 (maximal length at the occlusal level) and M6 (maximal width at the occlusal level). Our PCA analyses include the previous bivariate plot measurements in addition to M3 (maximal metaconid-metastylid length, the double knot), M4 (maximum length of the preflexid), and M5 (maximum length of the postflexid).

Anatomical elements. - dtxP1: deciduous upper first premolar; dtxP2: deciduous upper second premolar; dtxP3: deciduous upper third premolar; dtxP4: deciduous upper fourth premolar; dtxM1: deciduous upper first molar; dtmp1: deciduous lower first premolar; dtmp2: deciduous lower second premolar; dtmp3: deciduous lower third premolar; dtmp4: deciduous lower fourth premolar; dtmm1: deciduous lower first molar; txI1: upper first incisive; txI2: upper second incisive; txP2: upper second premolar; txP3: upper third premolar; txP4: upper fourth premolar; txM1: upper first molar; tmi1: lower first incisor; tmi2: lower second incisor; tmp2: lower second premolar; tmp3: lower third premolar; tmp4: lower fourth premolar; tmm1: lower first molar; tmm2: lower second molar; tmm3: lower third molar; mc3: third metacarpal; calc: calcaneum mt3: third metatarsal; 1ph3: first phalanx of the central digit; 2ph3: second phalanx of the central digit; 3ph3: third phalanx of the central digit; lt.: left; rt.: right.

Repositories and institutional abbreviations.-IGF: Sezione Geologia e Paleontologia, Museo di Storia Naturale, Università di Firenze, Italy; L: Livensovka, Russia; MNHN: Muséum National d'Histoire Naturelle, Paris, France; NHMB: Naturhistorisches Museum, Basel, Switzerland; NHML: Natural History Museum, Lyon, France; RN: Roca-Neyra; UCBL-FSL: Université Claude Bernard-1, Paleontological Collection, Lyon, France; USNM: National Museum of Natural History, Washington D.C, USA. 

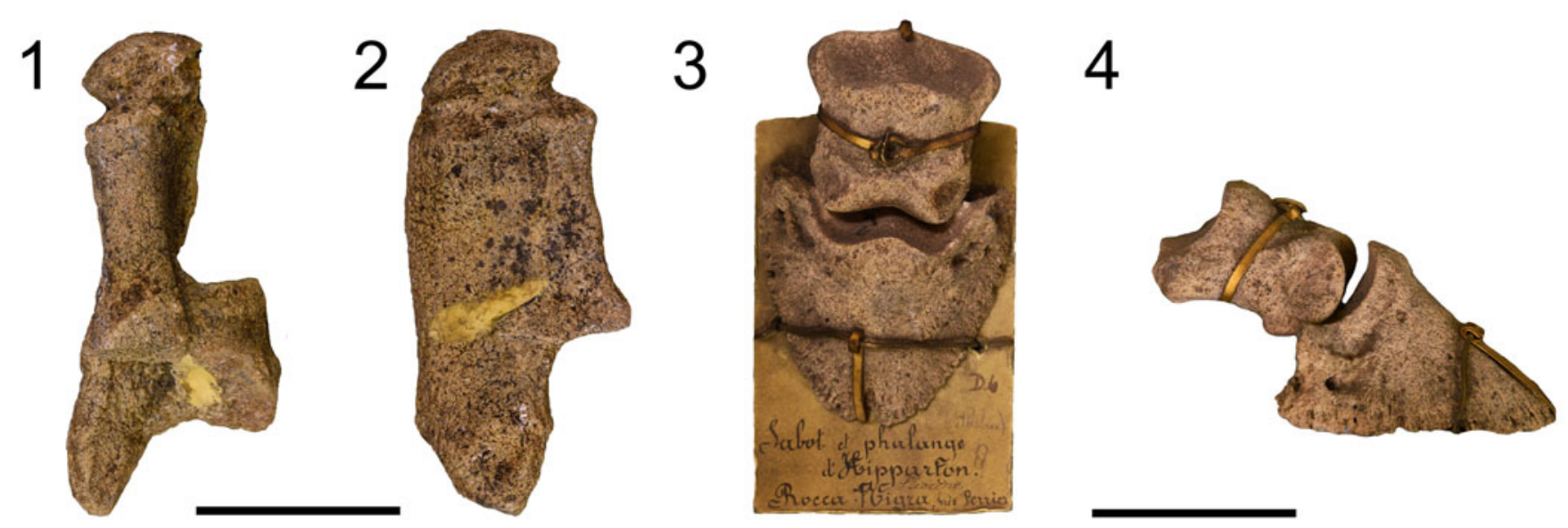

Figure 2. Plesiohipparion cf. P. rocinantis from Roca-Neyra. UCBL-FSL 211232, right calcaneum in cranial and lateral views (1, 2); UCBL-FSL 211733, articulated left second and third phalanges, in cranial and lateral view $(\mathbf{3}, \mathbf{4})$. Scale bars $=5 \mathrm{~cm}$.

\section{Systematic paleontology}

Order Perissodactyla Owen, 1848

Family Equidae Gray, 1821

Subfamily Equinae Gray, 1821

Tribe Hipparionini Quinn, 1955

Genus Plesiohipparion Qiu, Huang, and Guo, 1987

Type species.—Hipparion rocinantis Hernández-Pacheco, 1921.

Plesiohipparion cf. ?P. rocinantis (Hernández-Pacheco, 1921) Figure 2

1973 Hipparion sp. Eisenmann and Brunet (not figured). 2004 Hipparion rocinantis; Palombo and Valli (not figured).

Holotype.-Unknown.

Lectotype.-A lower third/fourth premolar, described in Hernández-Pacheco (1921) and Alberdi (1974), figured in Alberdi (1974, fig. 6.4), from La Puebla de Almoradier, Early Pleistocene, Spain.

Description.-Figure 2.1, 2.2 illustrates the right calcaneum in cranial and lateral views of UCBL-FSL 211232. This element has a slender morphology with tuber calcaneum being well developed, although it is damaged in the lateral and cranial sides. The tuber calcaneum may not have been completely fused, and therefore this individual may have been a subadult. The central body is narrow, and the distal portion is elongated, whereas the sustentaculum tali for articulation with the astragalus connection is developed antero-posteriorly. In lateral view, the processus coracoideus is well developed.

Figure 2.3 and 2.4 shows the articulated second and third phalanges UCBL-FSL 211733, in cranial and lateral view. The second and third phalanges are articulated with an artificial support. The $2 \mathrm{ph} 3$ is a short bone, expanded medio-laterally proximally. The proximal articular surface is inclined from the palmar to dorsal aspect, with the attachment of the ligamentum sesamoideum rectum of the flexor tuberosity being strongly developed. The proximal articular surface has robust swellings for the medial and lateral scar for the ligamentum collaterale of third digit for $1 \mathrm{ph} 3$ and $2 \mathrm{ph} 3$ articulation. In cranial view (Fig. 2.3), the distal aspect presents the medial and lateral hollowed scars for attachment of the ligamentum collaterale, which binds the second and third phalanges of the central digit. The distal articular facet presents a gentle sinuous curve in dorsal view, angular in lateral view.

The $3 \mathrm{ph} 3$ proximal articular surface presents a sinuous curve, as in $2 \mathrm{ph} 3$, for the $2 \mathrm{ph} 3$ articulation; the processus palmaris and medialis are not elongated. The medial and lateral grooves for attachment of the ligamentum collaterale are placed below the lateral margin of the proximal articulation. The margin of the foot's sole is curled.

Material.-Right calcaneum (UCBL-FSL 211232); left second phalanx of the central digit (UCBL-FSL 211733); left third phalanx of the central digit (UCBL-FSL 211733); two third metatarsals MNHN 1948-13-11 and NHMB RN 98, (Eisenmann and Brunet, 1973; table 2, p. 114).

Remarks.-Plesiohipparion rocinantis (following Alberdi, 1974; Bernor et al., 1996, 2015; Pueyo et al., 2016) was initially described by Hernández-Pacheco (1921) from the Early Pleistocene of La Puebla de Almoradier (Spain), based on a few isolated remains (see Zouhri and Bensalmia, 2005). Villalta (1948) described a new species from the locality of Villarroya, Hipparion crusafonti Villalta, 1948. Pirlot (1956) and Forsten (1968) were the earliest authors to remark about the morphological similarities between $H$. rocinantis and $H$. crusafonti. Alberdi (1974) considered H. rocinantis HernándezPacheco, 1921 to be a valid species, recognizing Villalta's species at the subspecies level, $H$. rocinantis crusafonti. Alberdi (1986), followed by Bernor et al. (1996, 2015) and Azanza et al. (2016), included $H$. rocinantis crusafonti in $H$. rocinantis Hernández-Pacheco, 1921, considering the latter to be the formal name of the species. Qiu et al. (1987), followed by Bernor et al. (1996, 2015) and Bernor and Sun (2015), 
recognized this species as being a member of the Plesiohipparion clade. As such, its biogeographic range extends across the PlioPleistocene boundary, reported from La Puebla de Almoradier, Las Higueruelas, Villarroya (Alberdi, 1974, 1986), Roca-Neyra (France; Alberdi, 1986; Palombo and Valli, 2004; present paper), and Kvabebi (Georgia; Vekua, 1972; Alberdi, 1986).

As reported in the previous description and in the results shown in various morphometrical analyses (Figs. 5.1, 5.2, 7.4, our data, and Eisenmann and Brunet, 1973) we ascribe this sample to ?Plesiohipparion cf. P. rocinantis. Our results suggest close morphological and morphometric similarities of the RocaNeyra sample with the species from Villarroya and Kvabebi, and more broadly with the Plesiohipparion clade (see bivariate plots and Log10 ratio diagrams).

Tribe Equini Gray, 1821

Genus Equus Linnaeus, 1758

Type species._Equus caballus Linnaeus, 1758.

Equus cf. E. livenzovensis Bajgusheva, 1978

Figure 3
1973 Equus cf. E. stenonis; Eisenmann and Brunet, p. 106, fig. 1. 2004 Equus cf. E. stenonis; Palombo and Valli.

Holotype.-An incomplete skull (L-4) stored in the Ethnographic Museum at Livensovka, Rostov, Russia (Bajgusheva, 1978, p. 98, fig. 1).

Description.-Figure 3 includes the Roca-Neyra Equus sample, UCBL-FSL 211735 left tmp4 (Fig. 3.1), tmm1 (Fig. 3.2), and tmm2 (Fig. 3.3), probably belonging to the same individual. The left tmp4 is well preserved; the metaconid-metastylid (double knot) are round, separated by a shallow V-shaped linguaflexid; the preflexid is large, and its mesial margin has a long buccally projecting pli; the postflexid is antero-posteriorly elongated, with its mesiolabial margin extending into the isthmus separating metaconid and metastylid. The protoconid and the hypoconid are large, with a small pli caballinid on the mesial margin of the hypoconid. The entoconid is broad. The posterior root is broken.

The left tmm1 (Fig. 3.2) has a damaged labial margin of the protoconid; the metaconid-metastylid (double knot) has a round shape, separated by a V-shaped linguaflexid; the preflexid is
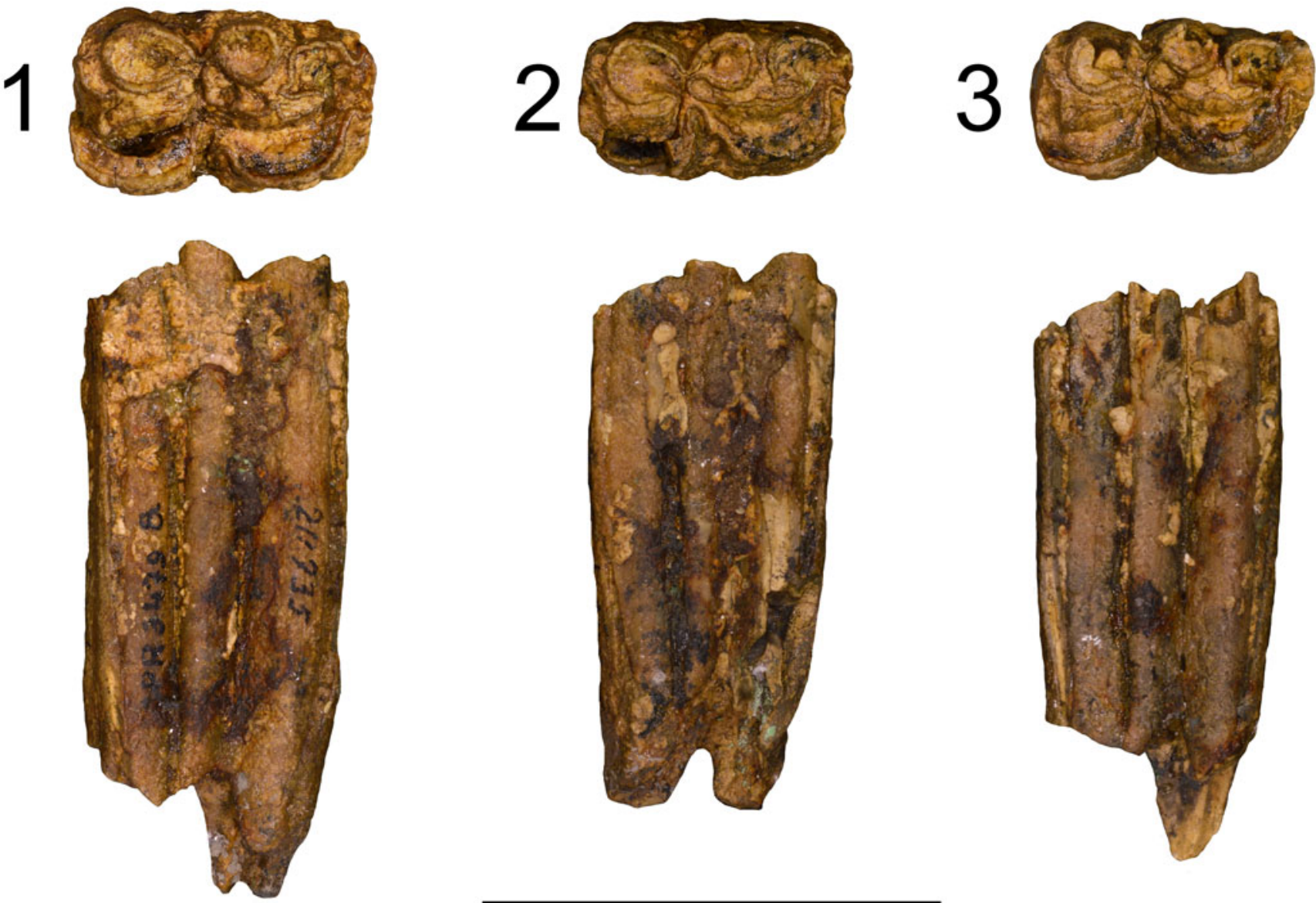

Figure 3. Equus cf. E. livenzovensis from Roca-Neyra. UCBL-FSL 211735, left lower fourth premolar (1); UCBL-FSL 211735, left lower first molar (2); UCBL-FSL 211735, left lower second molar (3). The specimens, probably belonging to the same individual, are represented in occlusal and lingual view. Scale bar $=5 \mathrm{~cm}$. 
narrow, constricted labio-lingually, with a prominent mesio-labial pli; the postflexid is antero-posteriorly elongated, with a worn lingual margin projecting into the isthmus between metaconid and metastylid; the hypoconid is large, with a worn pli caballinid on the anterior margin; the entoconid is broad, with a worn pointed cusp on the postflexid labial margin. Both roots are preserved.

The left tmm2 (Fig. 3.3) is broken on the lingual margin of the double knot, but the rounded shape of metaconid and metastylid are apparent; the metaconid and metastylid are separated by the V-shaped linguaflexid; the preflexid is elongated mesiodistally and constricted labial-lingually; the postflexid is anteroposteriorly elongated, with its mesial margin projecting into the isthmus separating metaconid-metastylid; the protoconid and hypoconid are large, with a diminuitive pli caballinid on the hypoconid mesial margin. The entoconid is broad, with a worn pointed cusp on the postflexid labial margin. The distal root is broken.

Figure 4 provides occlusal profiles of the Roca-Neyra Equus sample UCBL-FSL $211735 \mathrm{tmp} 4$, tmm1, and tmm2, compared to North American E. simplicidens (Hagerman), European E. livenzovensis (Kapry), E. stenonis vireti (Saint Vallier), E. stenonis (Olivola), and extant African E. grevyi (Kenya) complete lower tooth rows. UCBL-FSL 211735 exhibits a mixture of occlusal features, shared with E. simplicidens and E. stenonis. The round shape of metaconid-metastylid is comparable to E. simplicidens and E. livenzovensis and, on the lingual side, does not exhibit the typical stenonine squared-pointed metastylid shape seen in the samples from Saint Vallier, Olivola, and Kenyan Equus spp. Noteworthy is the presence of a pointed metastylid on the lingual side of E. stenonis vireti, E. stenonis, and E. grevyi. Therefore, due to these morphological features, but in particular the metaconid-metastylid morphology, we ascribe the UCBL-FSL 211735 sample to Equus cf. E. livenzovensis.

Material.-Apparently associated left mandibular fourth premolar, first molar, and second molar (UCBL-FSL 211735), figured in Eisenmann and Brunet (1973, p. 106, fig. 1).

Remarks.-Equus livenzovensis Bajgusheva, 1978, is the oldest Equus species in Europe and it is recorded in the type locality of the Khapry area, in the Italian locality of Montopoli, and in the Spanish localities of El Rincón-1 and Huèlago (Alberdi et al., 1997; Palombo and Alberdi, 2017). All of these localities have been correlated to the Plio-Pleistocene boundary, 2.6 Ma. The species was erected by Bajgusheva in 1978, based on the Equus sample for the Khapry area, and its validity has been confirmed by Azzaroli (2000). Equus livenzovensis occurs in the Villafranchian Montopoli Faunal Unit (MNQ16b) at the beginning of the Pleistocene. The faunal turnover recorded in the Montopoli Faunal Unit is marked by the disappearance of warm-forest species such as Tapirus arvernensis Croizet and Jobert, 1828, Mammut borsoni Hays, 1834, Sus arvernensis Depéret, 1890, Ursus minimus Devèze de Chabrioland and Bouillet, 1827, and Stephanorhinus jeanvireti Guérin, 1972, and the first occurrence in the Villafranchian record of Puma pardoides Owen, 1846, Mammuthus gromovi Alexeeva and Garutt, 1965, Stephanorhinus etruscus Falconer, 1868, Eucladoceros falconeri Dawkins, 1868, Gazella borbonica, and Equus livenzovensis (Rook and Martìnez-Navarro, 2010; Cherin et al., 2013; Pandolfi, 2013; Bartolini Lucenti, 2017; Pandolfi et al., 2017, 2019; Rook et al., 2017; Bernor et al., 2018a, b; Cirilli et al., in press).

\section{Statistical analysis}

"Hipparion".--In order to better determine the taxonomic identity of the Roca-Neyra "Hipparion" sample we compared it to the Plio-Pleistocene European "Hipparion" samples from Layna, Perpignan, Kvabebi and Villarroya. We have utilized the following morphometrical and statistical methodologies: bivariate plots, Log10 ratio diagrams and PCA.

Figure 5 includes bivariate plots for "Hipparion" third metatarsal (5.1) and second phalanx of the central digit (5.2). Figure 5.1 is mt3 maximum length (M1) versus distal articular width (M11). The Roca-Neyra specimens, MNHN 1948-13-11 and NHMB RN 98, plot close to $P$. rocinantis from Villarroya and " $H$." rocinantis from Kvabebi (Georgia, Vekua, 1972), and they also plot close to P. longipes from Pavlodar, Akkaşdağı (Koufos and Vlachou, 2005) and Çalta (Bernor and Sen, 2017). Plesiohipparion houfenense (data from Bernor et al., 2015) is the largest species considered in the plots (Fig. 5.1). A central group includes the primitive late Miocene species $H$. primigenium, C. sinapensis, and C. africanum. Eurygnathohippus feibeli is included in this sample, whereas Cremohipparion mediterraneum specimens are slightly longer than those of $C$. sinapensis, and $C$. matthewi is the smallest and most slender species, plotting close to $C$. mediterraneum. A second group includes the robust species Sivalhippus perimensis, S. turkanensis, and Proboscidipparion heintzi. It is remarkable that "H." crassum plots in this group, close to Proboscidipparion heintzi and Sivalhippus turkanensis.

Figure 5.2 shows maximal length (M1) versus distal width (M6) of the second phalanx of the central digit. Two separate groups can be observed in this plot. The first one, which includes the medium- to small-size species $H$. primigenium, $C$. africanum, E. feibeli, C. matthewi, "Hipparion crassum," and "Hipparion fissurae," and the second with the larger species $S$. turkanensis, $P$. heintzi, and $P$. rocinantis. In this plot, UCBL-FSL 211733 is located within the larger forms, close to the Kvabebi sample, $P$. rocinantis and $S$. turkanensis. Moreover, $P$. rocinantis from Villarroya is slightly narrower than $P$. heintzi from Çalta. Hipparion fissurae and $H$. crassum are included in the medium- to small-size species (H. primigenium, C. africanum, and E. feibeli) with $C$. matthewi, which remains the narrowest individual of the entire sample.

Figure 6 is the mc3 Log 10 ratio diagrams using the Höwenegg Hippotherium sample as standard (Bernor et al., 1997). Figure 6.1 compares species of Cormohipparion, Eurygnathohippus, and Cremohipparion. As previously discussed in Bernor et al. (2020), the primitive $C$. sinapensis and $C$. africanum are likely ancestral to E. feibeli and C. mediterraneum. Eurygnathohippus feibeli and C. mediterraneum follow the C. sinapensis and C. africanum Log10 line trajectories, even when the morphology is clearly more slender (M3-M10 in E. feibeli and M3, M10, M11 in C. mediterraneum). Cremohipparion matthewi is the smallest and most slender species considered in the analysis, and its trend reflects a plausible origin from $C$. moldavicum, the sister-taxon of C. mediterraneum (Bernor et al., 2016). 


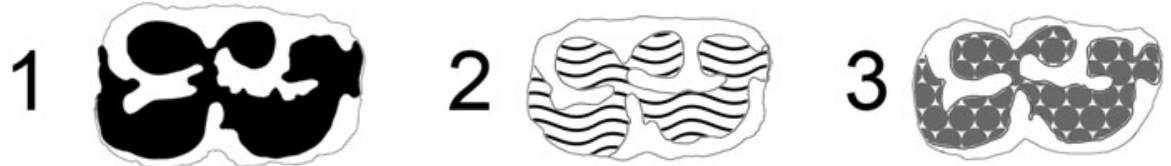

\section{Roca Neyra, UCBL-FSL211735}

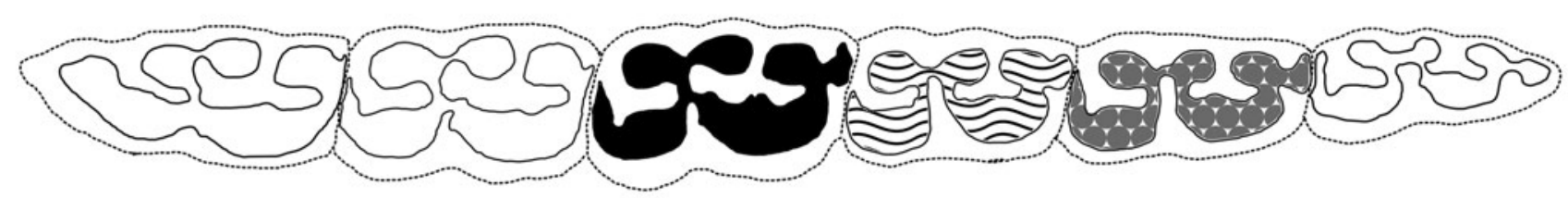

Equus simplicidens, Hagerman, USNM12573

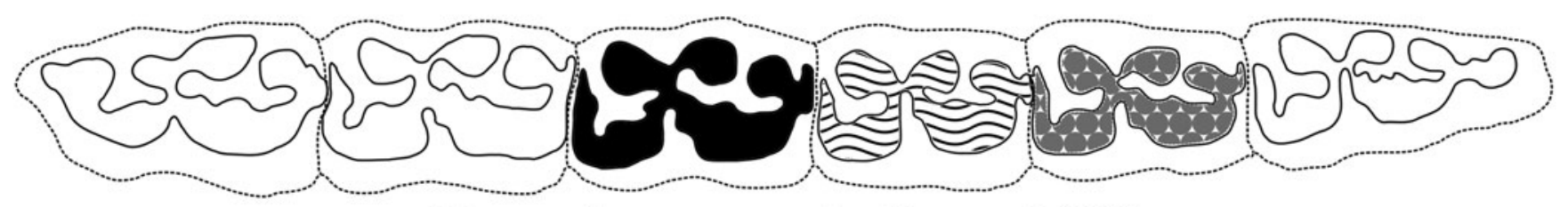

Equus livenzovensis, Kapry, L229

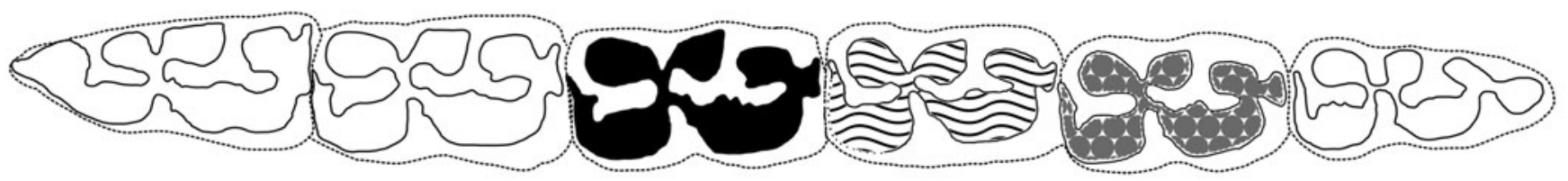

Equus stenonis vireti, Saint Vallier, NHML20.163464

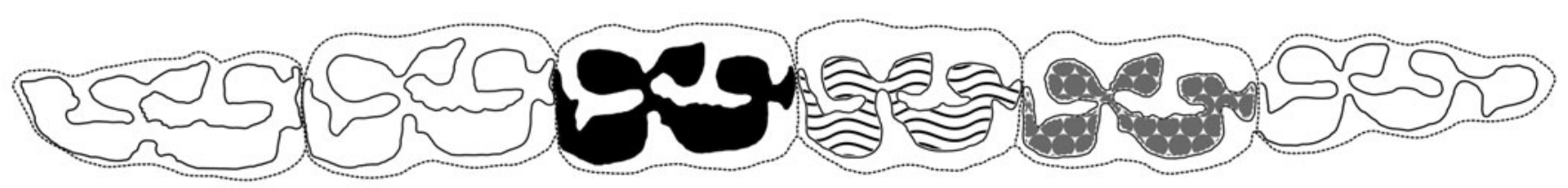

Equus stenonis, Olivola, IGF11024

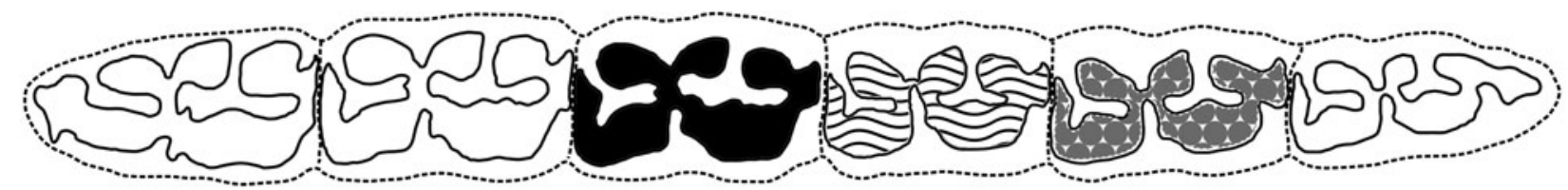

\section{Equus grevyi, Kenya, USNM163228}

Figure 4. Anatomical comparison of the occlusal morphology of Equus cf. E. livenzovensis from Roca Neyra (1-3) with Equus simplicidens, Equus livenzovensis, Equus stenonis vireti, Equus stenonis from Olivola, and the extant Equus grevyi. Black $=\mathrm{tmp} 4$, undulating black lines $=\mathrm{tmm} 1$, gray circles $=\mathrm{tmm} 2 . \mathrm{Scale}$ bar $=5 \mathrm{~cm}$.

Figure 6.2 plots species of Cormohipparion, Sivalhippus, and Proboscidipparion. Compared to C. sinapensis and the Eurygnathohippus-Cremohipparion species, a different pattern is shown by Sivalhippus and Proboscidipparion. They have a wider, more robust midshaft width (M3) and a relatively shallow midshaft depth (M4), larger values in M5-M10 and M8. Çalta Proboscidipparion heintzi has a robust pattern similar to the
Sivalhippus lineage: M1, M3, M10, and M8 are narrower, but the other measurements are included between the S. turkanensis and $S$. perimensis deviation. We cannot rule out that this similarity is due to convergent evolution within the "Sivalhippus Complex" (Bernor et al., 1996). "Hipparion" crassum from Perpignan displays a similar morphological pattern to Proboscidipparion heintzi, albeit with a reduced length and overall size. 

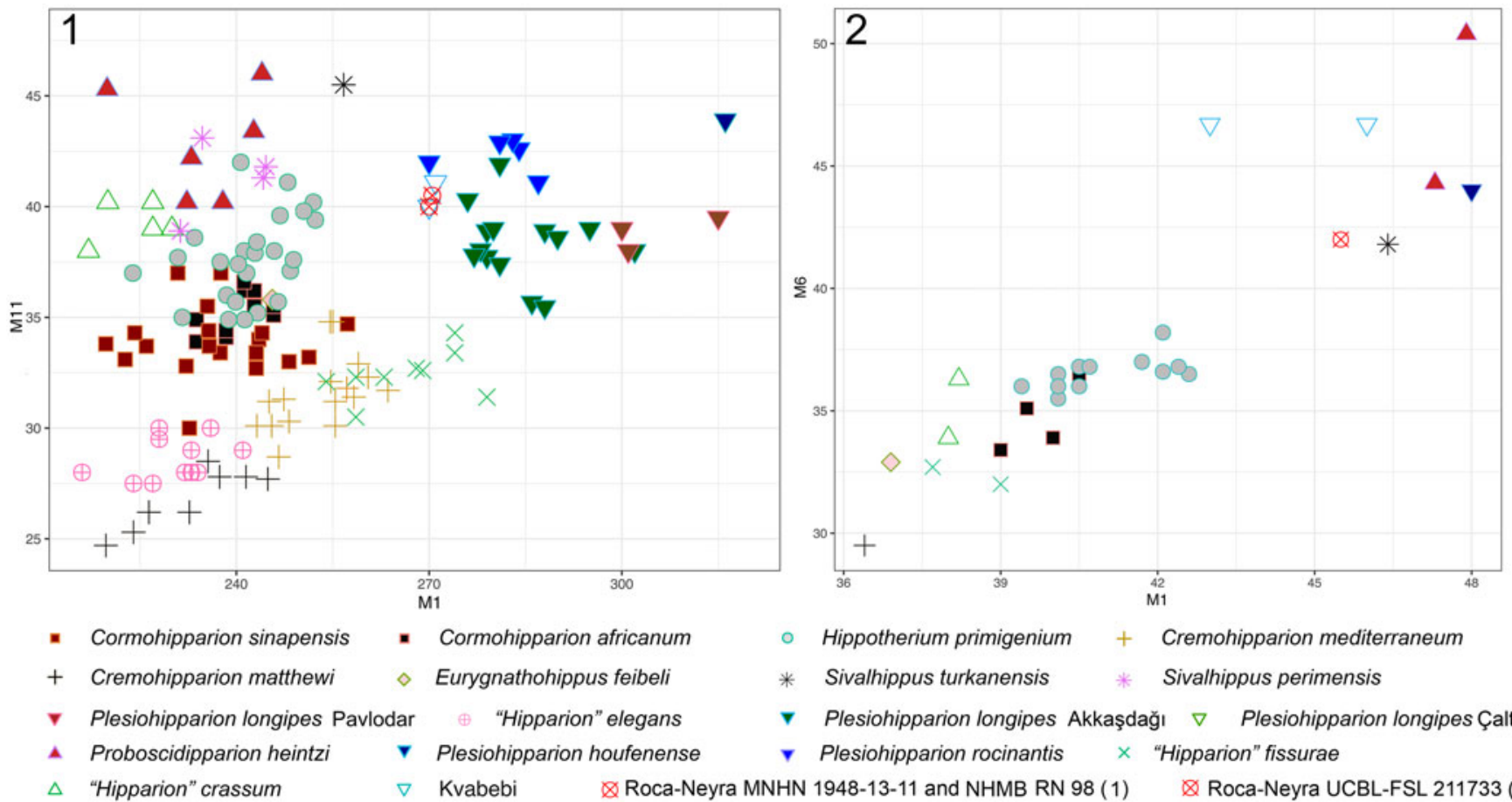

- Cormohipparion africanum

- Hippotherium primigenium + Cremohipparion mediterraneum

- Eurygnathohippus feibeli

* Sivalhippus turkanensis

* Sivalhippus perimensis

v Plesiohipparion longipes Akkaşdağı $\nabla \quad$ Plesiohipparion longipes Çalta

v "Hipparion" elegans

> Plesiohipparion rocinantis

$\times$ "Hipparion" fissurae

$\triangle$ "Hipparion" crassum

$\nabla \quad$ Kvabebi

\& Roca-Neyra MNHN 1948-13-11 and NHMB RN 98 (1)

Q Roca-Neyra UCBL-FSL 211733 (2)

Figure 5. Bivariate plots for third metatarsal (1) and second phalanx of the central digit (2), comparing the Plesiohipparion cf. P. rocinantis from Roca-Neyra with a suite of Miocene, Pliocene and Early Pleistocene hipparions. The source of data is reported in Material and methods.
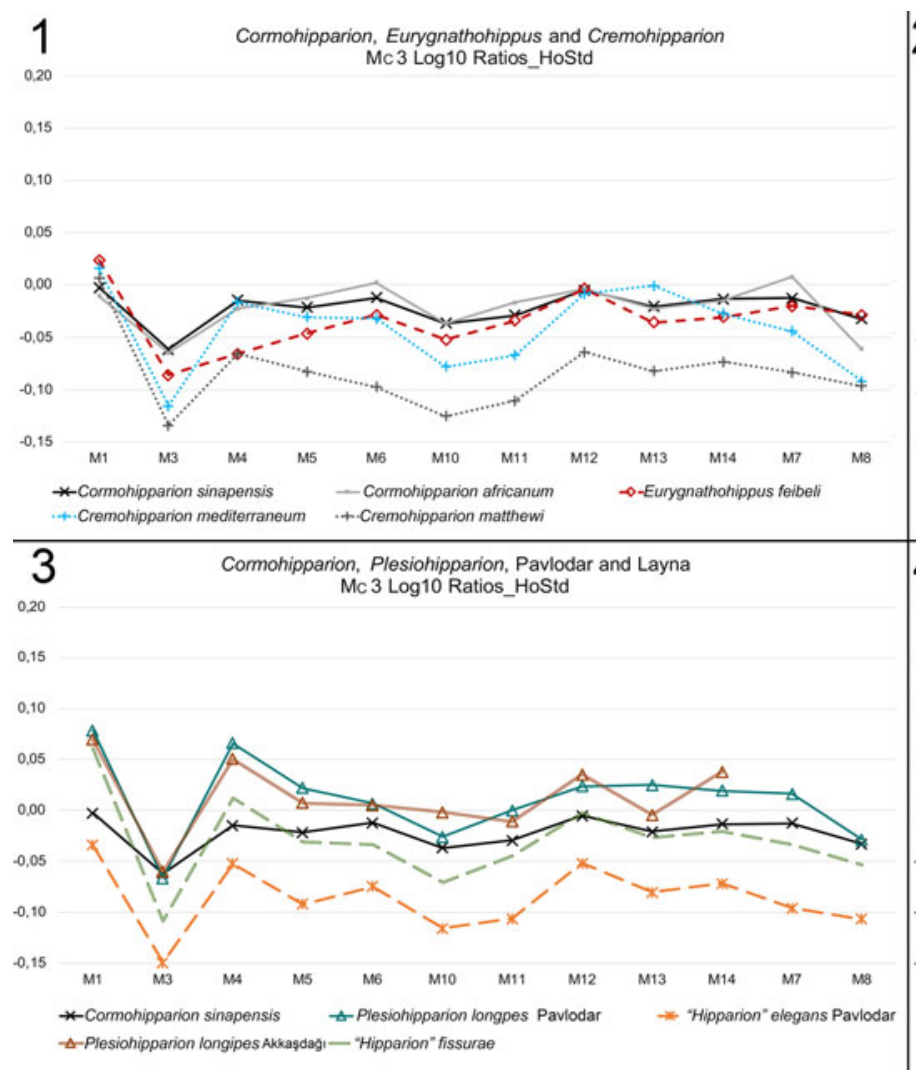

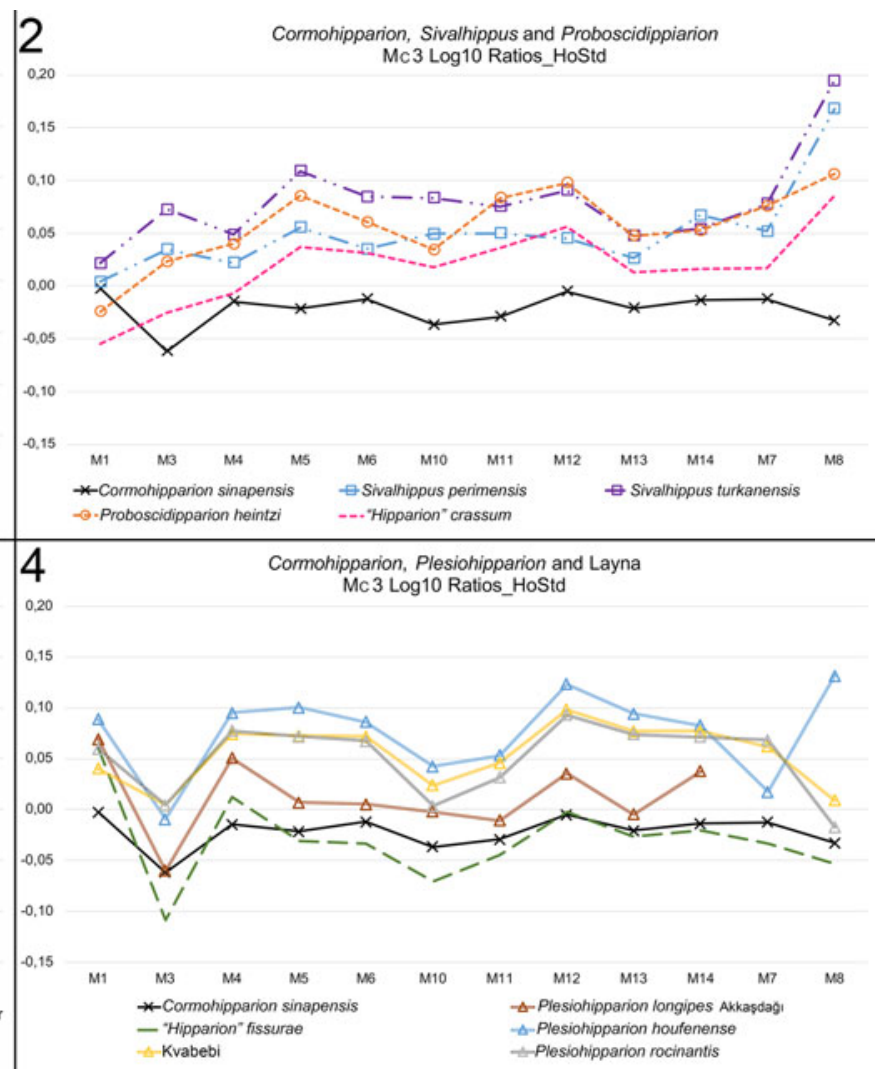

Figure 6. Log10 Ratio diagrams analysis for third metacarpal (Hippotherium primigenium from Höwenwgg, Germany used as standard; Bernor et al., 1997), comparing a suite of Miocene, Pliocene and Early Pleistocene hipparions (1-4). The source of data is reported in Material and methods. 
Figure 6.3 plots Cormohipparion sinapensis and Plesiohipparion longipes from Pavlodar and Akkaşdağı, with the Pavlodar "Hipparion" elegans and Layna "Hipparion" fissurae samples. Plesiohipparion longipes from Pavlodar and Akkaşdağ 1 exhibits the same pattern, with a slender morphology marked by M1-M3, and an overall similar morphology (even larger M10 in P. longipes form Akkaşdağ 1 and larger M13 in $P$. longipes from Pavlodar). Noteworthy, the "Hipparion" elegans pattern shows a very similar morphology to "Hipparion" fissurae, even if the latter has generally larger dimensions and a more elongated maximum length (M1), and different morphological aspect of the proximal and distal epiphysis (Alberdi and Alcalà, 1999).

Figure 6.4 plots species of Cormohipparion and Plesiohipparion with the Layna sample. The Plio-Pleistocene Plesiohipparion species ( $P$. rocinantis and $P$. houfenense) have generally larger dimensions when compared to the Late Miocene $P$. longipes from Akkaşdağı, even if their pattern exhibits the same slender morphology (M1-M3) and the same morphology of the distal epiphysis, with wider values in M5, M6, and M13. "Hipparion" rocinantis from Kvabebi shows an identical morphology and pattern to $P$. rocinantis from Villarroya, and together they are comparable with $P$. longipes, but with a shorter maximal length (M1), a narrower distal maximal supraarticular width (M10), and a wider distal maximal depth of the lateral condyle (M13). Plesiohipparion houfenense is the largest species in this plot, and its pattern is similar to $P$. rocinantis.
"Hipparion" fissurae is more slender than the Plesiohipparion group, nevertheless its morphology remains intermediate between the Plesiohipparion and Cremohipparion groups.

Figure 7 shows the corresponding $\mathrm{mt} 3 \log 10$ ratio diagrams using the Höwenegg Hippotherium primigenium mean. These plots produce results for each clade that are similar to those calculated for the mc3 $\log 10$ ratio diagrams.

Figure 7.1 plots species of Cormohipparion, Eurygnathohippus, and Cremohipparion. The Eurygnathohippus feibeli and C. matthewi morphology is similar to C. sinapensis and C. africanum, even more slender. Cremohipparion matthewi is similar to C. mediterraneum, but smaller and narrower.

Figure 7.2 plots species of Cormohipparion, Sivalhippus, and Proboscidipparion. Sivalhippus turkanensis and S. perimensis have an almost identical pattern, even if the African species shows larger dimensions. Proboscidipparion heintzi exhibits a pattern comparable to $S$. perimensis. Furthermore, the "Hipparion" crassum trend is similar to P. heintzi, except for a small M10 and its general narrower dimensions.

Figure 7.3 plots species of Cormohipparion and Plesiohipparion with the Pavlodar and Layna samples. As reported in Figure 6.3, P. longipes exhibits an identical morphology to the $P$. longipes sample from Akkaşdağ 1 and Çalta, even if the P. longipes from Akkaşdağ (M1). Furthermore, the remarkable similarities between "Hipparion" elegans and "Hipparion" fissurae can be observed, even if "Hipparion" elegans from Pavlodar remains larger.

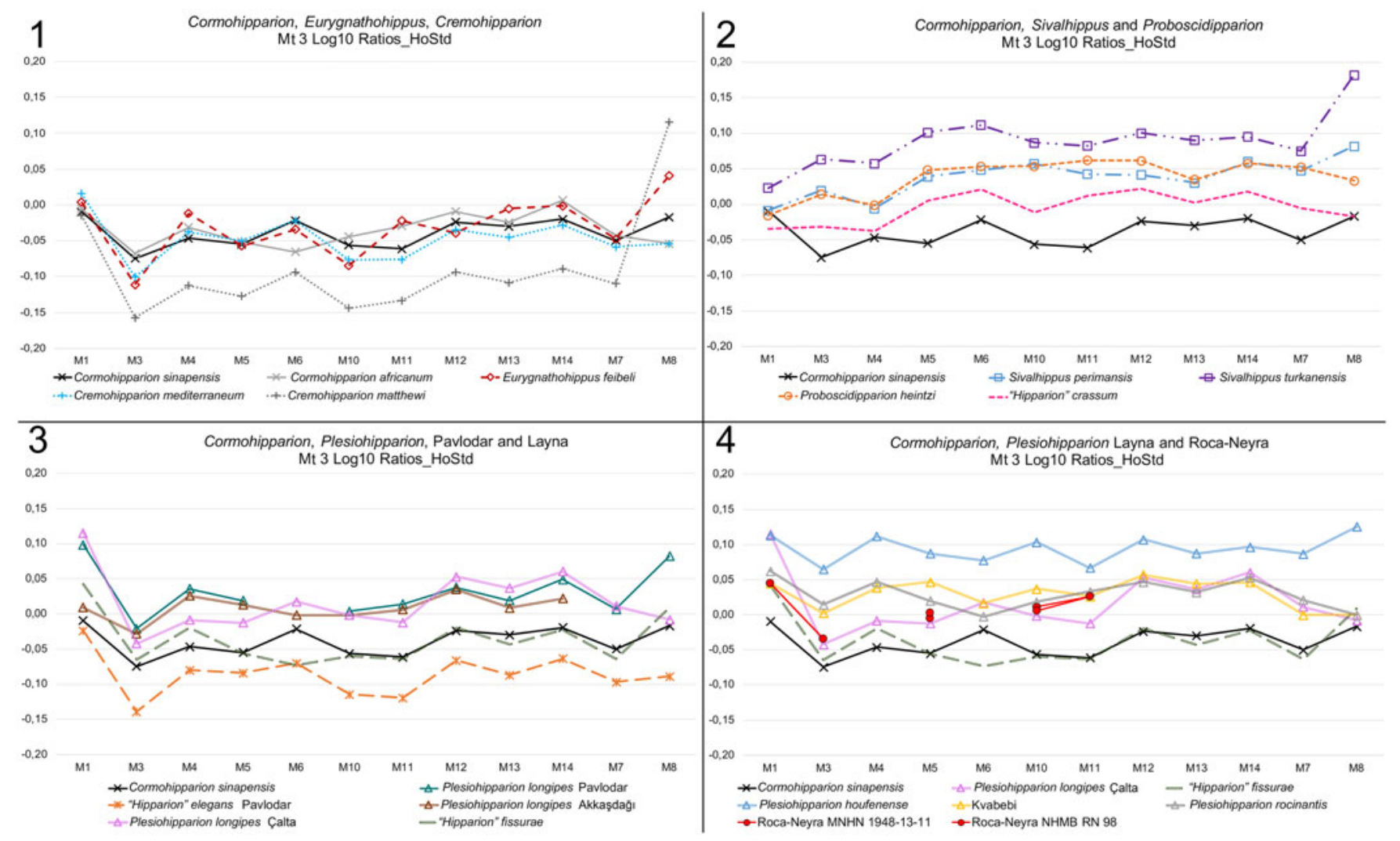

Figure 7. Log10 Ratio diagrams analysis for third metatarsal (Hippotherium primigenium from Höwenwgg, Germany used as standard; Bernor et al., 1997), comparing a suite of Miocene, Pliocene, and Early Pleistocene hipparions (1-4). The source of data is reported in Material and methods. Plesiohipparion cf. P. rocinantis from Roca-Neyra is included in (4). 
Figure 7.4 plots species of Cormohipparion and Plesiohipparion with the Layna sample. The $P$. longipes trajectory (Pavlodar, Akkaşdağ 1 , and Çalta) is likewise found in the Plio-Pleistocene species $P$. rocinantis and $P$. houfenense, even if $P$. longipes from Çalta exhibits a more elongated maximal length (M1) and wider dimension of the proximal articular width (M6). Hipparion rocinantis from Kvabebi has an almost identical morphology to $P$. rocinantis from Villarroya, whereas $P$. houfenense is the largest Plesiohipparion species. "Hipparion" fissurae is the slenderest species when compared to the Plesiohipparion group, with a morphology intermediate between the Plesiohipparion and Cremohipparion groups (Figure 6.4). Finally, the two Roca-Neyra specimens (MNHN1948-13-11 and NHMB RN 98; data from Eisenmann and Brunet, 1973) show morphology and dimensions equivalent to $P$. rocinantis from Villarroya and Kvabebi, respectively, confirming the evidence presented in the bivariate plots. The Kvabebi material includes skull, maxillary cheek teeth, and mandibular cheek teeth that compare well with Plesiohipparion (see Vekua, 1972).

Figure 8.1, 8.2 provides PCAs for $\mathrm{mc} 3$ and $\mathrm{mt} 3$, respectively. In the mc3 Principal Component Analysis, PC1 and PC2 account for most of the variance with $89.5 \%$ ( $\mathrm{PC} 1=$ 76.5\%; $\mathrm{PC} 2=13.0 \%$ ). In $\mathrm{mt} 3, \mathrm{PC} 1$ and $\mathrm{PC} 2$ account for $83.7 \%$ of the cumulative variance $(\mathrm{PC} 1=73.4 \%$; $\mathrm{PC} 2=$ $10.3 \%$ ) (a summary of the variance components is reported in Table 2). In Figure 8.1, 8.2, PC1 indicates a progressively more slender shape from positive to negative values, whereas PC2 indicates a more elongated morphology, from negative to positive values. The results described in the bivariate plots and $\log 10$ Ratios analyses are here confirmed, both in Figure 8.1, 8.2. Three different areas can be described, defined by the following species. A morphologically primitive assemblage represented by the late Miocene species includes $H$. primigenium, $C$. sinapensis, and C. africanum, with E. feibeli and C. mediterraneum slightly separated from one another. These are the primitive "Hipparion" morphologies with C. sinapensis, E. feibeli, and C. mediterraneum (see Bernor et al., 2020). A derived Plesiohipparion group (with larger and more elongated metapodials compared to the primitive European and African late Miocene species), including $P$. longipes, $P$. rocinantis, $P$. houfenense, and the Kvabebi sample, which by these analyses suggests their grouping with $P$. rocinantis. Another more robustly built mc3 group includes $S$. turkanensis, S. perimensis, $P$. heintzi, and "H." crassum. Cremohipparion matthewi is separated from the entire sample by its small size and slenderness, but shows a relationship to Cremohipparion mediterraneum (also, Bernor et al., 2016 related it to C. moldavicum). "Hipparion" elegans plots within the Cremohipparion group, between $C$. mediterraneum and C. matthewi, and "H." fissurae plots between $C$. mediterraneum and the Plesiohipparion group. "Hipparion" crassum plots close to Proboscidipparion heintzi, and this evidence supports its referral to "Proboscidipparion" crassum.

Figure $8.2(\mathrm{mt} 3)$ exhibits the same species clusters shown in Figure 8.1, but packed closer together with slight differences. The variability seen in the "H." elegans group overlaps with the Cremohipparion group, whereas " $H$." fissurae remains intermediate between Cremohipparion and Plesiohipparion.
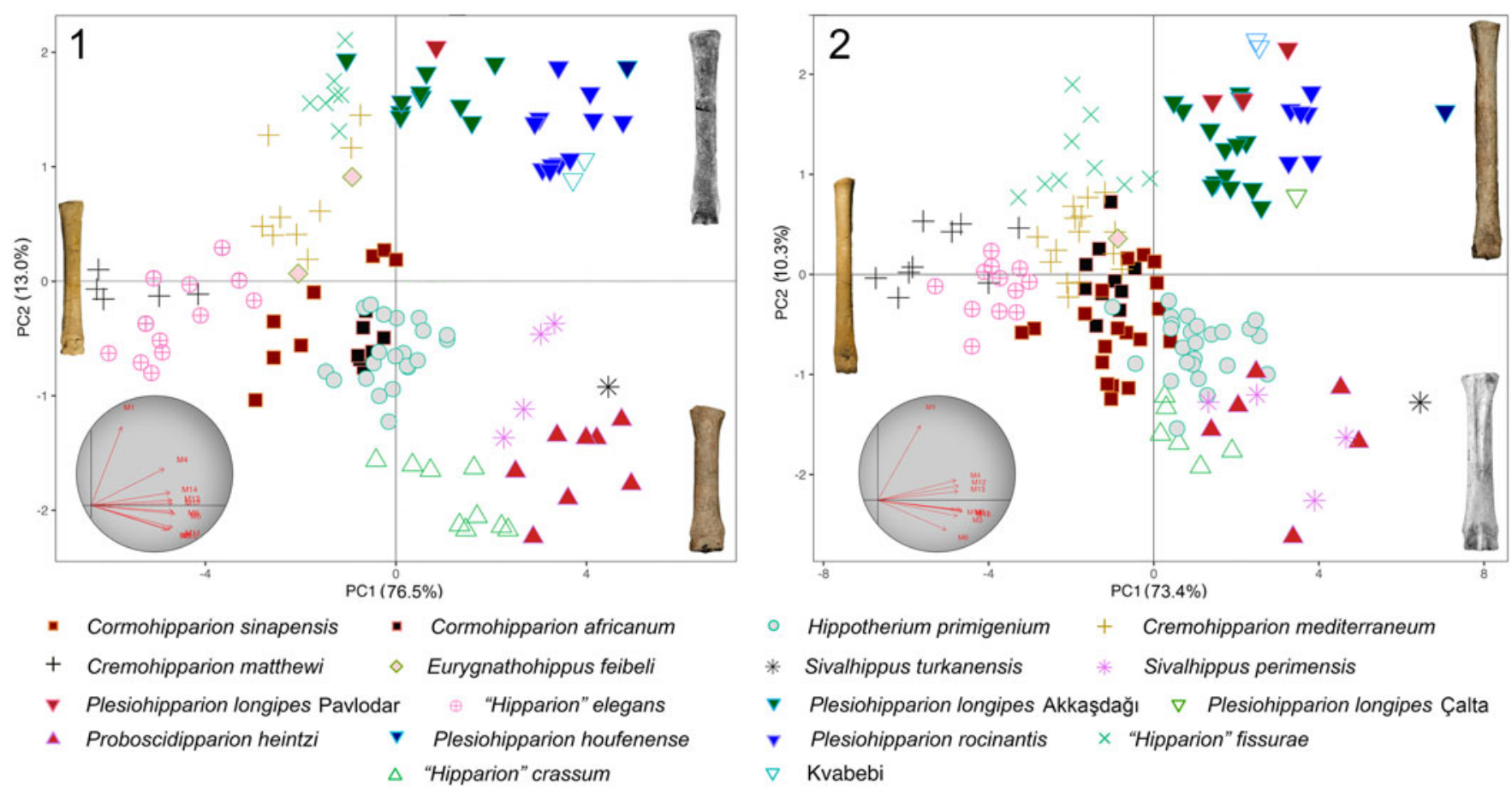

Figure 8. Principal Component Analysis for third metacarpal (1) and third metatarsal (2) on a suite of Miocene, Pliocene, and Early Pleistocene hipparions. Loadings distribution in PC1 and PC2 for third metacarpal (1) and third metatarsal (2) are shown in the biplot diagrams, left lower corner on both graphs. Mc3 images of Cremohipparion matthewi (Sahabi), Plesiohipparion longipes (Akkaşdağ1, Koufos and Vlachou, 2005), and Proboscidipparion heintzi (Bernor and Sen, 2017). Mt3 images of Cremohipparion matthewi (Sahabi), Plesiohipparion longipes (Çalta, Bernor and Sen, 2017), and Proboscidipparion heintzi (Eisenmann and Sondaar, 1998). The complete sample used for this analysis is shown in supplementary table 1 for mc 3 and supplementary table 2 for mt 3. 
Table 1. Anatomical measurements (following Eisenmann et al., 1988; Bernor et al., 1997) of the Roca-Neyra equid sample.

\begin{tabular}{|c|c|c|c|c|c|c|c|c|c|c|c|c|c|c|}
\hline SPEC_ID & Species & Element & Side & Age & M1 & M2 & M3 & M4 & M5 & M6 & M7 & M8 & M9 & M10 \\
\hline UCBL-FSL 211232 & Plesiohipparion cf. P. rocinantis & calc & $\mathrm{rt}$ & $2.6 \pm 0.02$ & 100.2 & 64.9 & 17.8 & 27.4 & 42.9 & 50.3 & 50.3 & & & \\
\hline UCBL-FSL 211733 & Plesiohipparion cf. P. rocinantis & $3 \mathrm{ph} 3$ & lt & $2.6 \pm 0.02$ & 61.5 & 58.5 & 63.9 & 22.6 & 39.1 & & & & & \\
\hline UCBL-FSL 211735 & Equus cf. E. livenzovensis & tmp4 & lt & $2.6 \pm 0.02$ & 31.6 & 27.9 & 18.1 & 10.1 & 14.1 & 20.3 & 17.6 & 17.4 & 18.1 & 61.2 \\
\hline UCBL-FSL 211735 & Equus cf. E. livenzovensis & $\mathrm{tmm} 2$ & lt & $2.6 \pm 0.02$ & 29.9 & & 16.8 & 8.8 & 12.4 & 17.2 & 15.2 & 16.2 & 52.6 & \\
\hline
\end{tabular}

"Hipparion" crassum plots close to the variability seen in the Proboscidipparion-Sivalhippus plots.

Equus.-In the Equus sample, statistical analyses are provided through bivariate plots (Figs. 9.1, 10.1, and 11.1) and PCA (Figs. 9.2, 10.2, and 11.2) in tmp4, tmm1, and tmm2. Bivariate plots and PCAs for each element are shown together, to better determine the species clusters.

Figures 9.1, 10.1, and 11.1 are bivariate plots for UCBL-FSL 211735 tmp4, tmm1, and tmm2, respectively. The measurements plotted are maximum occlusal length (M1) versus occlusal width (M6). In all the bivariate plots, UCBL-FSL 211735 is plotted close to the larger E. stenonis vireti specimens and E. suessenbornensis (Akhalkalaki, Georgia). Equus simplicidens shows an M1 variation comparable to the E. stenonis vireti, E. stenonis from Olivola, and E. stenonis from Upper Valdarno, with a narrower width. Equus sp. from Senèze plots between the E. stenonis group and E. stehlini. Extant E. grevyi overlaps with the E. stenonis group (E. stenonis vireti, E. stenonis Olivola, E. stenonis Upper Valdarno, and Equus sp. Senèze), and in Figures 9.1 and 10.1 overlaps with the largest $E$. simplicidens specimens.

Figures 9.2, 10.2, and 11.2 are PCAs for tmp4, tmm1, and tmm2, respectively. In tmp4 (Fig. 9.2), PC1 and PC2 account the $80.7 \%$ of the variance (PC1 $=68 \%$; $\mathrm{PC} 2=12.7 \%$ ). In tmm 1 (Fig. 10.2), PC1 and PC2 explain $85.9 \%$ of the cumulative variance $(\mathrm{PC} 1=68.3 \%$; PC2 $=17.6 \%)$. In tmm2 (Fig. 11.2), PC1 and $\mathrm{PC} 2$ amount to $83.3 \%$ of the cumulative variance $(\mathrm{PC} 1=67.9 \%$; $\mathrm{PC} 2=15.4 \%)$. PC1 segregates species by maximum occlusal length (M1) from positive to negative values, from largest to smallest. PC2 differs among diagrams: in tmp4, it is mainly represented by M4 (maximum length of the preflexid) in positive values and M5 (maximum length of the postflexid) for negative, whereas in tmm1 and tmm2 it is explained by M4-M5 and M6 (maximal width at the occlusal level), which have opposite values (the variance components are reported in Table 3).

Equus simplicidens is always included within the variability of E. stenonis, whereas E. stenonis vireti overlaps the larger portion of the E. stenonis sample. Remarkably, a progressive clustering can be observed through E. stenonis, Equus sp. from Senèze, and E. stehlini, which correlates E. stehlini with Equus sp. (Senèze) instead of the typical E. stenonis samples from Saint Vallier, Olivola, and Upper Valdarno Basin. UCBL-FSL 211735 is plotted outside of any species variability range, and it is always placed between E. stenonis vireti and Equus suessenbornensis. Equus suessenbornensis is the species with the widest dimensions found in the analysis. Finally, E. grevyi once again plots within E. stenonis variability.

\section{Evolutionary and biogeographic implications}

Hipparionine lineages.-Old World Hipparionini have their earliest occurrence in the lowermost late Miocene of the Vienna Basin Pannonian C, 11.4-11.0 Ma at the base of Mammal Neogene Unit MN9, and it is termed the Cormohipparion Datum (Bernor et al., 2017; formerly the "Hipparion Datum" of Berggren and Van Couvering, 1974). Hipparions rapidly diversified across Eurasia and Africa, evolving into several genus-level lineages (Bernor et al., 1990, 1996, 2010). Their acme in terms of lineage diversity and abundance was MN12 (7.6-6.8 Ma), followed by a sharp decline by the end of MN13 (5.3 Ma) resulting in the extinction of several lineages, including Cormohipparion, Hippotherium, Hipparion s.s., Sivalhippus (Bernor et al., 1996), Baryhipparion (Qiu et al., 1987), Shanxihippus (Bernor et al., 2018a), and Cremohipparion (except a single species in China, C. licenti Qiu, Huang, and Guo, 1987). The occurrence of hipparions through the Plio-Pleistocene interval becomes progressively rarer, so that the co-occurrence of "Hipparion" with Equus in the Pleistocene is known from relatively few Eurasian localities.

China retained hipparions into the Pliocene and Pleistocene, including two Asian lineages, Plesiohipparion and Proboscidipparion (Qiu et al., 1987; Bernor et al., 1996; Bernor and Sun, 2015). Plesiohipparion has a substantial diversity in the late Miocene-Pleistocene of China, being represented by

Table 2. Importance of components of Principal Component Analysis for the "Hipparion" sensu lato sample, Figure 8.

\begin{tabular}{|c|c|c|c|c|c|c|c|c|c|c|}
\hline \multicolumn{11}{|l|}{$\mathrm{mc} 3$} \\
\hline Importance of components: & PC1 & PC2 & PC3 & PC4 & PC5 & PC6 & PC7 & PC8 & PC9 & PC10 \\
\hline Standard deviation & 2.7667 & 1.1409 & 0.56185 & 0.42459 & 0.38535 & 0.35347 & 0.31950 & 0.28554 & 0.22819 & 0.19669 \\
\hline Proportion of Variance & 0.7655 & 0.1302 & 0.03157 & 0.01803 & 0.01485 & 0.01249 & 0.01021 & 0.00815 & 0.00521 & 0.00387 \\
\hline Cumulative Proportion & 0.7655 & 0.8956 & 0.92719 & 0.94522 & 0.96007 & 0.97256 & 0.98277 & 0.99092 & 0.99613 & 1.00000 \\
\hline \multicolumn{11}{|l|}{$\mathrm{mt} 3$} \\
\hline Importance of components: & PC1 & PC2 & PC3 & PC4 & PC5 & PC6 & PC7 & PC8 & PC9 & PC10 \\
\hline Standard deviation & 2.7096 & 1.0150 & 0.66053 & 0.5967 & 0.54210 & 0.43863 & 0.34197 & 0.30647 & 0.2738 & 0.25154 \\
\hline Proportion of Variance & 0.7342 & 0.1030 & 0.04363 & 0.0356 & 0.02939 & 0.01924 & 0.01169 & 0.00939 & 0.0075 & 0.00633 \\
\hline Cumulative Proportion & 0.7342 & 0.8372 & 0.88086 & 0.9165 & 0.94585 & 0.96509 & 0.97679 & 0.98618 & 0.9937 & 1.00000 \\
\hline
\end{tabular}



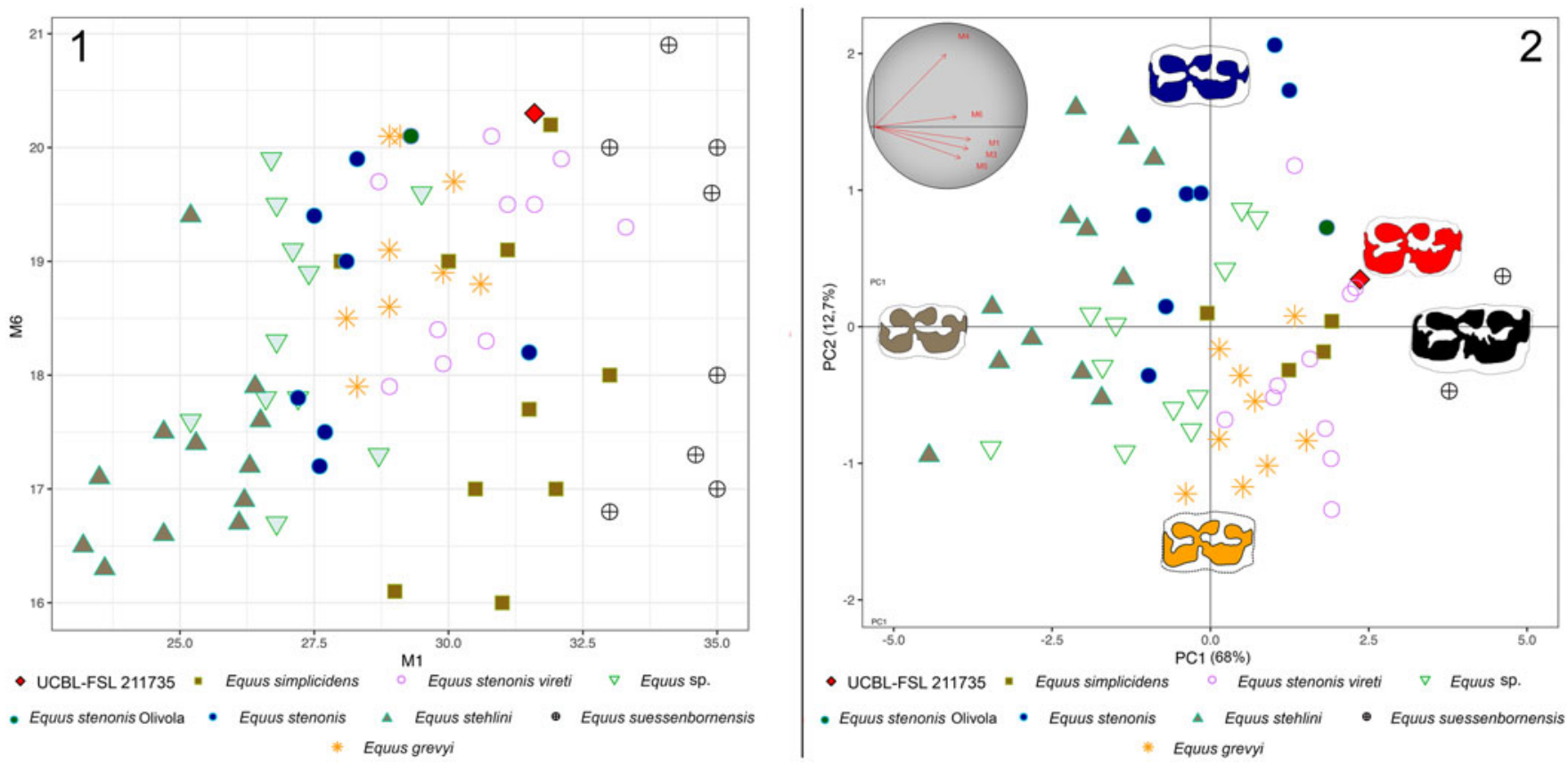

Figure 9. Lower fourth premolar bivariate plots (1) and Principal Component Analysis (2), comparing Equus cf. E. livenzovensis from Roca-Neyra with a suite of Early Pleistocene Equus and with the extant Equus grevyi. Loadings distribution in PC1 and PC2 are shown in the biplot diagram. Occlusal surface profile of Equus suessenbornensis (black), Roca-Neyra (red), Equus stenonis (blue), Equus stehlini (dark green), and Equus grevyi (orange). The complete database for Principal Component Analysis is reported in supplementary table 3.

three species, Plesiohipparion houfenense, Plesiohipparion huangheense Qiu, Huang, and Guo, 1987, and Plesiohipparion shanxiense Bernor, Sun, and Chen, 2015 (Qiu et al., 1987; Bernor and Sun, 2015; Bernor et al., 2015).

Plesiohipparion species have skulls lacking a preorbital fossa and the nasal bones are not retracted. Their cheek teeth are similar to Proboscidipparion, having protocones that are moderately elongate, flattened lingually, and sometimes having a lingual indentation. Overall, they are similar to species of Sivalhippus (Bernor and Hussain, 1985; Wolf et al., 2013). Plesiohipparion lower cheek teeth characteristically have lingually pointed metaconids and metastylids, broad linguaflexids, and
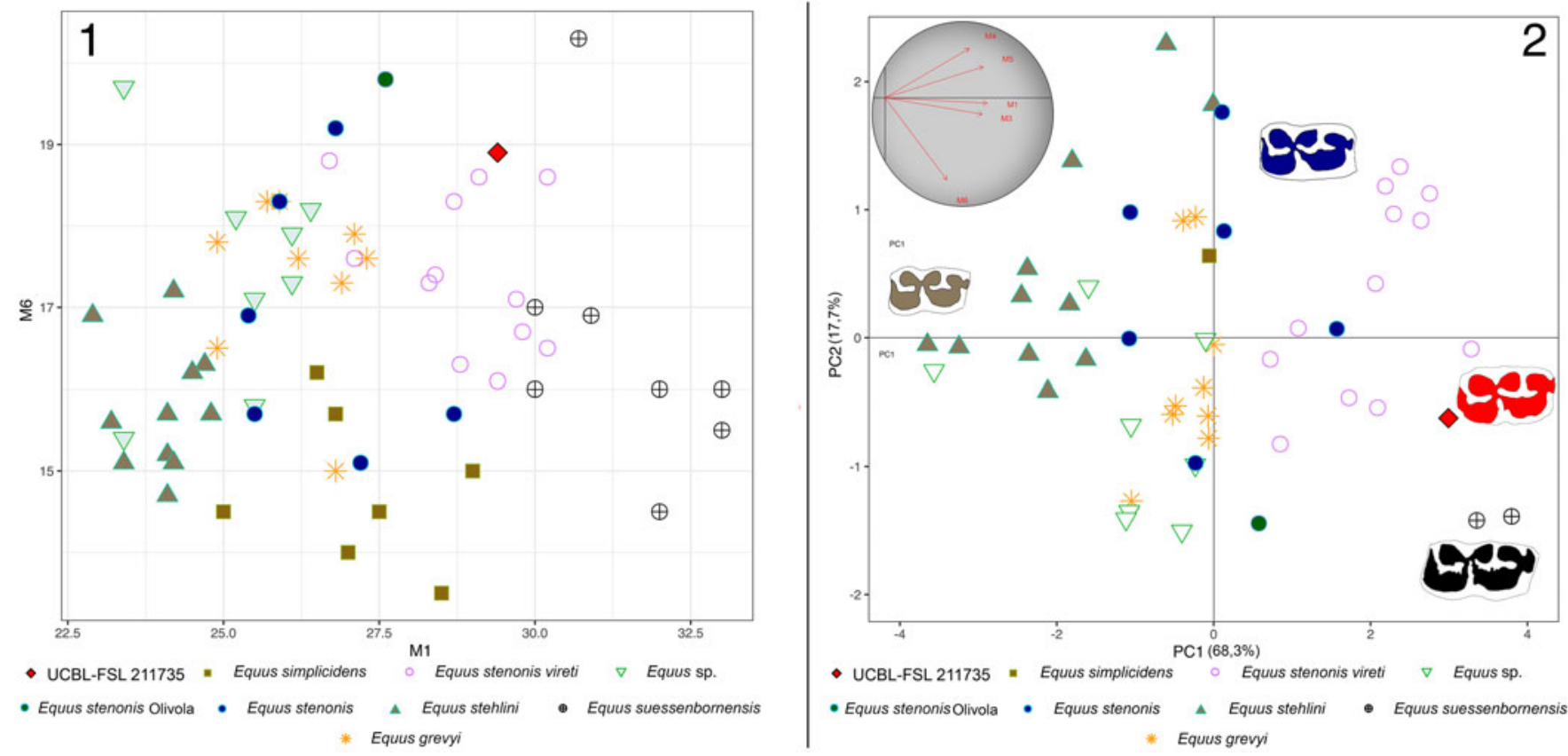

Figure 10. Lower first molar bivariate plots (1) and Principal Component Analysis (2), comparing Equus cf. E. livenzovensis from Roca-Neyra with a suite of Early Pleistocene Equus and with the extant Equus grevyi. Loadings distribution in PC1 and PC2 are shown in the biplot diagram. Occlusal surface profile of Equus suessenbornensis (black), Roca-Neyra (red), Equus stenonis (blue), and Equus stehlini (dark green). The complete database for Principal Component Analysis is reported in supplementary table 4. 

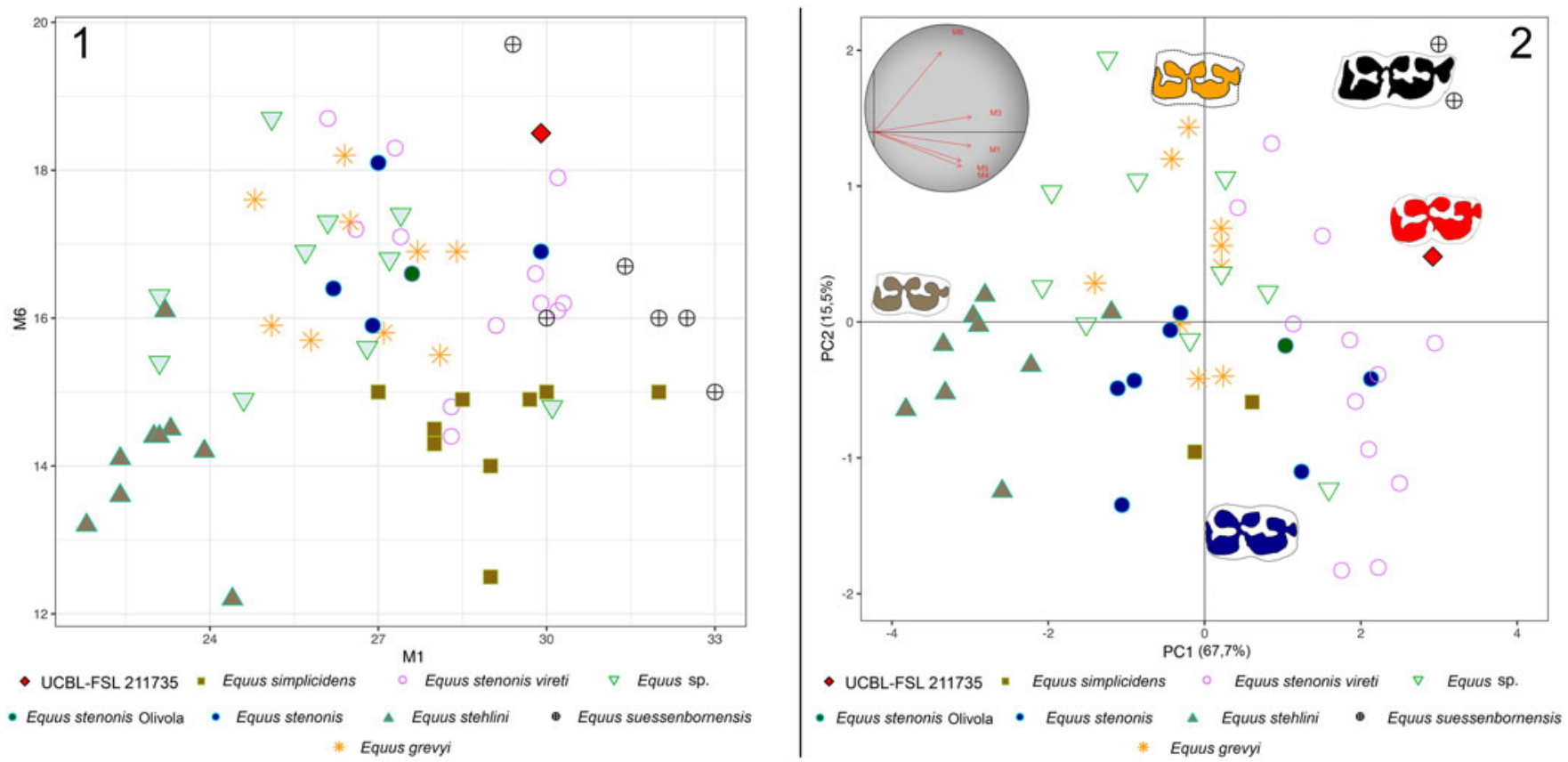

Figure 11. Lower second molar bivariate plots (1) and Principal Component Analysis (2), comparing Equus cf. E. livenzovensis from Roca-Neyra with a suite of Early Pleistocene Equus and with the extant Equus grevyi. Loadings distribution in PC1 and PC2 are shown in the biplot diagram. Occlusal surface profile of Equus suessenbornensis (black), Roca-Neyra (red), Equus stenonis (blue), Equus stehlini (dark green), and Equus grevyi (orange). The complete database for Principal Component Analysis is reported in supplementary table 5.

very broad ectoflexids penetrating deeply into the isthmus separating metaconid and metastylid of the molars. Third metatarsals are very elongated in Plesiohipparion species.

The Proboscidipparion lineage includes two successive species in China, P. pater Qiu, Huang, and Guo, 1987 in the latest Miocene and early Pliocene, and the very large form Proboscidipparion sinense Sefve, 1927 in later earliest to Late Pleistocene (Sefve, 1927; Qiu et al., 1987; Bernor et al., 1989; Bernor and Sun, 2015). Proboscidipparion has a large skull with an extraordinarily elongate snout that is downturned anteriorly, and strongly to very strongly retracted nasals (Bernor et al., 2018a).

Proboscidipparion pater has cheek teeth with protocones that are moderately elongated and lingually flattened, complex plications of fossettes, and mostly single pli caballins; maxillary cheek teeth are overall similar to Indian subcontinent
Sivalhippus. The lower cheek teeth have rounded metaconids, slightly squared metastylids, and deep linguaflexids that may be V- or U-shaped (Bernor and Sen, 2017, fig. 2). Proboscidipparion sinense (2.6-1.0 Ma) has maxillary cheek teeth with complex fossette plications, mostly single pli caballins, and protocones that are elongate and flattened lingually, as in P. pater. Lower cheek teeth have elongated tmp2 and tmm3, very elongate and shallow linguaflexids, rounded to pointed metaconids, mostly pointed metastylids, and elongate-deep linguaflexids (Bernor and Sun, 2015, fig. 4). Some Proboscidipparion sinense maxillary cheek teeth have smaller rounded protocones (Bernor and Sun, 2015, fig. 5). While strongly divergent in their skull morphology, Plesiohipparion and Proboscidipparion would appear to be closely related and derived from the Indian subcontinent Sivalhippus radiation. And, in fact, Sun et al. (2018)

Table 3. Importance of components of Principal Component Analysis for the Equus sample, Figures 9.2, 10.2, 11.2.

\begin{tabular}{|c|c|c|c|c|c|}
\hline tmp4 & & & & & \\
\hline Standard deviation & 1.8446 & 0.7991 & 0.7531 & 0.46803 & 0.4155 \\
\hline Proportion of Variance & 0.6805 & 0.1277 & 0.1134 & 0.04381 & 0.03453 \\
\hline Cumulative Proportion & 0.6805 & 0.8082 & 0.9217 & 0.96547 & 1.00000 \\
\hline tmm1 & & & & & \\
\hline Importance of components: & $\mathrm{PC} 1$ & PC2 & PC3 & $\mathrm{PC} 4$ & PC5 \\
\hline Standard deviation & 1.8484 & 0.94 & 0.64711 & 0.44447 & 0.28924 \\
\hline Proportion of Variance & 0.6833 & 0.1767 & 0.08375 & 0.03951 & 0.01673 \\
\hline $\operatorname{tmm} 2$ & & & & & \\
\hline Importance of components: & $\mathrm{PC} 1$ & PC2 & PC3 & PC4 & PC5 \\
\hline Standard deviation & 1.8397 & 0.8794 & 0.61534 & 0.57512 & 0.36418 \\
\hline Proportion of Variance & 0.6769 & 0.1547 & 0.07573 & 0.06615 & 0.02653 \\
\hline Cumulative Proportion & 0.6769 & 0.8316 & 0.90732 & 0.97347 & 1.00000 \\
\hline
\end{tabular}


identified two species of Sivalhippus in the late Miocene of China-S. platyodus (Sefve, 1927) and S. ptychodus (Sefve, 1927).

The Plesiohipparion lineage arose in Asia at the end of the Miocene, MN 13, and is known from Pavlodar, Russia (Gromova, 1952), Akkaşdağı, Turkey (Koufos and Vlachou, 2005), and Çalta, Turkey (Bernor and Sen, 2017). Bernor and Lipscomb (1991) identified an advanced Plesiohipparion, $P$. huangheense, occurring with Equus in the Early Pleistocene Turkish locality of Gülyazi (ca. 2.58 Ma). Jukar et al. (2018) identified a lower cheek tooth row of Plesiohipparion huangheense from 3.5-2.6 Ma Tatrot Formation horizons, India. Jukar et al. (2019) also identified a specimen of Eurygnathohippus sp. in these horizons, marking its first known extension of this lineage outside of Africa.

The early Pliocene locality of Çalta, Turkey includes the occurrence of two Asian Hipparion clades (Eisenmann and Sondaar, 1998; Bernor and Sen, 2017). Eisenmann and Sondaar (1998) recognized two species of hipparions, "Hipparion" longipes and "Hipparion" heintzi. Bernor and Sen (2017) recognized these as being referable to the Asian lineages Proboscidipparion heintzi and Plesiohipparion cf. P. longipes. Proboscidipparion heintzi is represented by a juvenile skull with strongly retracted nasals, cheek teeth (deciduous dtxP1-tx4) with short rounded protocones, and txM1 with more elongate protocone flattened lingually. The lower cheek teeth have rounded metaconids and metastylids (again, dptm2-4, tmm1), with the tmm1 having an extremely elongate linguaflexid. While still in their crypts, the permanent mandibular tmils are very large. The Çalta $P$. heintzi has a very short and robust mc3 and a short and massively built $1 \mathrm{ph} 3$ akin to Siwalik S. perimensis and African S. turkanensis (Bernor and Harris, 2003; Wolf et al., 2013). The Çalta Plesiohipparion cf. P. longipes has a very elongate and slender $\mathrm{mt} 3$ and elongate-slender $1 \mathrm{ph} 3$.

Forsten (2002) reported remains of the "Hipparion" crassum "Group" from the Pliocene of Europe. She defined the "Group" as having rounded to rounded-triangular metaconids and metastylids of the lower cheek teeth, and aligned her systematics with Alberdi (1989) who identified this "Group" as her "morphotype 4." Despite the strong divergence in skull characters of Chinese Plesiohipparion and Proboscidipparion, Forsten suggested that Plesiohipparion is the junior synonym of Proboscidipparion, which created a lasting taxonomic confusion. Plesiohipparion and Proboscidipparion are distinct lineages of generic status, differing profoundly in skull morphology and, we believe, postcranial anatomy (Qiu et al., 1987; Bernor et al., 1996, 2015; Bernor and Sun, 2015; present paper). Forsten identified "Hipparion" crassum as occurring in France, Italy, Spain, England, Hungary, Bulgaria, Romania, Ukraine, Moldova, Russia, Turkey (including Çalta), Azerbaijan, and China. Hipparions from these localities are united by their occurrence in Plio-Pleistocene horizons and have mixed cranial, dental, and postcranial morphologies.

The "Hipparion" crassum that occurs at Perpignan, France, is 4.1 Ma. (Clauzon et al., 2015). This species shows striking similarities to Proboscidipparion heintzi (Çalta, also ca. 4.0 Ma; Bernor and Sen, 2017) in its robustly built third metapodials. This evidence has been discussed in the morphometric and statistical analysis (Figs. 5-8). The maxillary cheek teeth have elongated second premolars, complex enamel plications, and short, rounded protocones. The mandibular cheek teeth have rounded to squared metaconids, more pointed metastylids, $\mathrm{V}$-shaped to elongate linguaflexids, and elongate third metapodials. A mandible, Pp208 (Depéret, 1890; Eisenmann, 2019; https://vera-eisenmann.com) has an elongate symphysis and tmi1-tmi2 hypertrophied with distinct lingual grooving, and tmp2-tmp4 with deeply extending ectoflexids approaching the isthmus separating metaconid-metastylid. These characters, in particular the short and robust proportions of the $\mathrm{mc} 3 \mathrm{~s}$ and $\mathrm{mt} 3 \mathrm{~s}$, are consistent with a referral to Proboscidipparion crassum. Alberdi and Alcalà (1999) referred also the equid sample from the early Pliocene of Dorkovo (Bulgaria), MN14 to Hipparion cf. H. crassum.

Crusafont and Sondaar (1971), Alberdi (1974), and Alberdi and Alcalà (1999) assigned the Layna Pliocene Hipparion to $H$. fissurae. Domingo et al. $(2007,2013)$ correlated Layna as being 3.91 Ma, confirming the earlier hypothesis on the age based on rodent remains made by López-Martínez (1989) and Sesé (2006). In particular, Alberdi and Alcalà (1999) described several other Spanish samples wherein " $H$." fissurae was identified as occurring from the Pliocene of La Gloria, Villalba Alta Rio 1, Orrios, and La Calera, late Ruscinian MN15. The maxillary cheek teeth from Layna (Alberdi, 1974, figs. 30, 40, 41, 43; Alberdi and Alcalà, 1999, fig. 40) have moderately complex plications, weakly developed pli caballins, and protocones that are triangular and oval to lingually flattened. The mandibular cheek teeth have lingually pointed metaconids and metastylids, and mandibular lower third molar has a distally extended talonid. The La Gloria 4 MT3 is very elongate and slender. These characters could suggest a referral to Plesiohipparion, P. fissurae. The morphometric and statistical analyses provided herein have also exhibited similarities with the Pavlodar "Hipparion" elegans and, more broadly, with the Cremohipparion group. These results could suggest that the Layna "Hipparion" could either be a small Eurasian Plesiohipparion or one of the longest limbed Cremohipparion of the Old World. This issue could be resolved if a skull were recovered from any of these localities because of the distinct differences in cranial morphology between Cremohipparion (nasal bones retracted and multiple facial fossae) and Plesiohipparion (nasals not retracted and no facial fossae). However, our results support observations made by Alberdi and Alcalà (1999) considering "H." fissurae a different and valid species, distinguished from Pavlodar " $H$." elegans.

Kvabebi 1 and Kvabebi 2, Georgia (Vekua, 1972; Eisenmann, 2019; https://vera-eisenmann.com) have two cheek tooth series with elongate tmp2, and remaining cheek teeth with lingually pointed metaconids and metastylids typical of Plesiohipparion suggesting a referral to Plesiohipparion crusafonti, which we consider to be a junior synonym of Plesiohipparion rocinantis. Agusti et al. (2009) have suggested a correlation of 3.09 Ma. based on a paleomagnetic chronology.

The Villarroya Hipparion was initially described by Villalta $(1948,1952)$ as Hipparion rocinantis and was recognized as resembling North American Neohipparion by Zhegallo (1978) and MacFadden (1984). Qiu et al. (1987), followed by Bernor et al. (1996, 2015) and Bernor and Sun (2015), recognized this species as being a member of the Plesiohipparion clade. The Villarroya Plesiohipparion rocinantis (Alberdi, 
1974) has a skull lacking a preorbital fossa, maxillary cheek teeth with moderately complex plications, small and simple pli caballins, and lingually flattened and labially rounded protocones. The mandibular cheek teeth have pointed metaconids and metastylids with deep, broadly U-shaped linguaflexids; mandibular tmm 3 has an elongate talonid. The first phalanges of the central digit are elongated and slender. These are all morphological hallmarks of Plesiohipparion.

These lines of evidence are supported in the morphometric and statistical analyses provided herein, wherein the Villarroya sample is consistently included in the Plesiohipparion group (Figs. 5.1, 6.4, 7.4, 8). Pueyo et al. (2016) recently cited the Villarroya "Hipparion" as the last occurring European assemblage in Western Europe, correlating it with the Reunion chron (C2r.1n, 2.128-2.148 Ma). Azanza et al. (2016) have challenged this correlation based on faunal evidence, with conflicting data from the micromammal assemblage. As a result, Azanza et al. (2016) correlated the Villarroya Mammal Zone with MNQ16b. If this revised correlation is correct, Villaroya, RocaNeyra, and Sésklo (Athanassiou, 2018) could represent the last occurrence of Plesiohipparion in Europe, at the Plio-Pleistocene transition.

Rook et al. (2017) described a small fragmentary left txM1 of an "Hipparion" sp. from Montopoli, Italy. While fragmentary, its size and simple occlusal morphology are akin to latest Miocene Cremohipparion sp., as found at Baccinello, Italy (Bernor et al., 2011). There is nothing in the morphology of this small Hipparion that would suggest an affinity either with Plesiohipparion or Proboscidipparion, but still, its generic status remains enigmatic.

The westernmost occurring hipparions come from the Red Crag deposits, Suffolk, England and are believed to be 3.8-2.8 Ma in age (Forsten, 2001). Based on a sample of $\sim 53$ teeth from the Ipswich Borough Council Museum (IPSMG), the Natural History Museum in London (BMNH), and the Museum of Comparative Zoology (MCZ), Harvard University, Forsten (2001) identified two Hipparion taxa, Hipparion sp.-crassum group and Proboscidipparion sp., from the Red Crag. Forsten (2001, fig. 1) identified eight cheek teeth, including four mandibular and two maxillary cheek teeth, as being Hipparion sp., and two mandibular cheek teeth as Proboscidipparion sp. The two maxillary cheek teeth, a right txP2 (IPSMG R 1939.85.57.5) and a left txM1 or txM2 (IPSMG R 1876 4.1) have the following salient features: very complex plications of the fossettes, bifid pli caballins, small rounded (the txP2) to lingually flattened short oval protocone (txM1-2). This morphology agrees with " $H$." crassum and we believe is a Proboscidipparion (see Bernor and Sun, 2015). The lower cheek teeth (Forsten, 2001, figs. 14) include a right tmp2 (ISPMG R 1876.4.10), a left tmp3or4 (ISPMG $\mathrm{R} 1876$ 4.5), right tmm1or2 (ISPMG R1939.85.57.8), and left tmp3or4 (ISPMG R 1876 4.9) that have broad linguaflexids, rounded metaconids, squared metastylids, and very broad linguaflexids referable to $H$. crassum, which we believe allied with Proboscidipparion. The two lower cheek teeth referred by Forsten (2001) to Proboscidipparion sp. are a right tmp2 (ISPMG 1939 85.57.4) and right tmm3 (ISPMG R $18764.7)$. The lower second premolar is very worn, elongated, and with rounded metaconid and squared metastylid and shallow U-shaped linguaflexid. The lower third molar has a rounded metaconid, lingually pointed metastylid, and broad linguaflexid, which compare with Proboscidipparion pater from China (Bernor and Sun, 2015). In our opinion, the entire Red Crag sample may indeed be a species of the Proboscidipparion clade, and not Plesiohipparion or "Hipparion" sensu lato.

Whereas the North African late Miocene has recorded occurrences of Cremohipparion, Sivalhippus, and Eurygnathohippus, the Plio-Pleistocene only records the hipparion species Eurygnathohippus pomeli (Eisenmann and Geraads, 2007) (Eisenmann and Geraads, 2007; Bernor et al., 2010). In the latest Miocene, a small slender-limbed form Eurygnathohippus feibeli occurred in Kenya, Ethiopia, Libya, and Morocco (Bernor and Harris, 2003; Bernor et al., 2010, 2012, 2020; Cirilli et al., 2020). In East Africa, Eurygnathohippus feibeli became very rare and was replaced by Eurygnathohippus woldegabrieli Berner et al., 2013 by 4.4 Ma, except at Ekora, Kenya (ca. 4.2 Ma; Bernor et al., 2010, 2013). Between 3.8 and 2.9 Ma Ethiopia records two Hipparion species, Eurygnathohippus hasumense Eisenmann, 1983 and Eurygnathohippus afarense (Eisenmann, 1976) (Eisenmann, 1983; Bernor et al., 2010). The latest recognized species from Olduvai Bed 1, Tanzania (1.9 Ma) to the 1 Ma. levels of Daka, Ethiopia and Cornelia, South Africa is Eurygnathohippus cornelianus Van Hoepen, 1930, a species with hypertrophied txI1 and txI2 and tmi1 and tmi2 with very high crowns. Other than a single occurrence of Eurygnathohippus from the Indian Tatrot (Jukar et al., 2019), the genus was restricted to Africa. Equus first occurs in East Africa at $2.3 \mathrm{Ma}$ (Bernor et al., 2010).

Equus dispersal.-The Equus dispersal into Eurasia was a major biochronologic event marking the lower Quaternary boundary, at $2.58 \mathrm{Ma}$. Associated with this immigration event was a strong paleoclimatic pulse recorded in terrestrial and marine strata, related to the initiation of a major glaciation pulse in the northern hemisphere (Lindsay et al., 1980; Azzaroli, 1983). The Equus Datum can be observed across Eurasia (2.58 Ma in Europe and 2.55 in China), and slightly shifted in sub Saharan Africa at 2.33 Ma (Rook et al., 2019).

Equus livenzovensis is the first appearing species in Europe and Western Asia (Caucasus), at ca. 2.58 Ma. Equus livenzovensis was originally recognized by Bajgusheva (1978) based on the cranial and postcranial sample from the Early Pleistocene of Livensovka and Kapry. Azzaroli (1982) first recognized the occurrence of Equus cf. E. livenzovensis in the Montopoli fauna, which has been studied in detail and confirmed by Bernor et al. (2018b). Alberdi et al. (1997) reported the occurrence of Equus livenzovensis from El Rincón-1 (Spain, Early Pleistocene), included in a faunal assemblage that shares many mammalian taxa with the Italian locality of Montopoli. Finally, Alberdi et al. (1998), Forsten (1998), and Azzaroli (2000) studied the type E. livenzovensis sample from Khapry, reaffirming its presence in the Caucasus area and validating the species.

Azzaroli $(1982,1992,2000,2002)$ provided a detailed discussion on the origin of Old World Equus. The genus Equus originated in North America, having been derived from Dinohippus, which had already evolved monodactyly (Barrón-Ortiz et al., 2019; Bravo-Cuevas and Jiménez-Hidalgo, 2019; Carranza-Castañeda, 2019). There is no consensus on which species is the earliest known "Equus," because opinions 
differ among authors (Eisenmann and Baylac, 2000; Eisenmann and Deng, 2005; Barrón-Ortiz et al., 2019). Bernor et al. (2019) have evaluated and supported Azzaroli and Voorhies (1993) hypothesis that North American Equus simplicidens is the most likely source for Old World first-occurring Equus. Equus simplicidens shares many characters with European E. livenzovensis and E. stenonis (see Bernor et al., [2019] for a comprehensive morphological review of the Early Pleistocene Equus species) and with the Chinese species E. eisenmannae Qiu, Deng, and Wang, 2004, E. qingyangensis Deng and Xue, 1999, and E. sanmeniensis Teilhard de Chardin and Piveteau, 1930 (see Sun and Deng, 2019), which represent the oldest Eurasian Early Pleistocene Equus species (ca. 2.6 Ma). Azzaroli (1982, 1992, 2002) and Bernor et al. (2018b, 2019) have stated that Eurasian Old World Equus species could be related to Kenyan Equus koobiforensis Eisenmann, 1983, which is the first species reported in the Early Pleistocene African fossil record.

Our results support observations by Bernor et al. (2019) that $E$. grevyi shares morphologic and morphometric dental features with the ancestral E. simplicidens and the Old World Equus stenonine species. Our analyses on the lower cheek teeth underscore an important evolutionary perspective: there is no significant morphometric difference in the E. simplicidens, E. stenonis vireti, E. stenonis, and E. grevyi lower cheek teeth, and the enamel occlusal morphology of the extant E. grevyi is found in the European fossil species E. stenonis. Furthermore, our analyses of the dental Equus sample from Roca-Neyra highlight the importance of E. livenzovensis, which exhibits mixed features with E. simplicidens and E. stenonis, and, with the support of the morphometric analysis explained in Bernor et al. (2018b), can be considered the primitive species for the radiation of the E. stenonis group. Following Azzaroli and Voorhies (1993) and Bernor et al. (2019), it appears that Equus simplicidens is plausibly ancestral to earliest occurring old World Equus, and the earliest Equus was very large (E. livenzovensis), and that in turn Equus stenonis and ultimately Equus grevyi are derived from early "stenonine" Equus spp.

\section{Hipparion-Equus sympatry}

The Roca-Neyra equid sample underscores an interesting ecological perspective in the European Plio-Pleistocene faunal turnover: the Hipparion (sensu lato)-Equus sympatric co-occurrence. In Europe, co-occurrence of Equus with "Hipparion" is rare, being represented at Montopoli in Italy (Rook et al., 2017, 2019; Bernor et al., 2018b), Roca-Neyra in France (Eisenmann and Brunet, 1973; Palombo and Valli, 2004; this paper), Gülyazi in Turkey (Bernor and Lipscomb, 1991), and possibly in the Khapry area (Eisenmann and Brunet, 1973; Bajgusheva et al., 2001). Africa has a protracted co-occurrence of Equus and Eurygnathohippus from 2.3 to $<1 \mathrm{Ma}$ (Bernor et al., 2010). Proboscidipparion co-occurs with Equus up to 1 Ma in China (Qiu et al., 1987). Furthermore, the possible youngest occurrence of "Hipparion" in Europe is recorded by the occurrence of Plesiohipparion rocinantis at Villarroya, which recently was estimated by Pueyo et al. (2016) to be $2.1 \mathrm{Ma}$, based on their paleomagnetic interpretation of the section. However, as previously explained, Azanza et al. (2016) questioned this age, suggesting a referral to the Mammal Zone MNQ16b.
Athanassiou (2018) reported new insights from Sésklo (Greece, Early Pleistocene) with the occurrence of Plesiohipparion cf. $P$. shanxiense and E. cf. E. stenonis at two different stratigraphic levels, correlated with the Mammal Zones MNQ16b and MNQ17. Athanassiou (2018) has commented that the Sésklo hipparionine population did not occur sympatrically with the genus Equus.

The Eurasian Hipparion Last Appearance Datum (LAD) is more controversial, and it is unlikely to have been synchronous. Our current understanding is that the latest occurrences of Plesiohipparion rocinantis from Villarroya and Plesiohipparion shanxiense from the Shanxi Basin indicate an approximate Early Pleistocene age of 2.0 Ma.

Considering Azanza et al.'s (2016) correlation of Villarroya to Mammal Zone MNQ16b, the youngest European hipparions would now appear to have occurred at the Plio-Pleistocene boundary, ca. 2.6 Ma, and not much later in time. This assertion is supported by reported occurrences of European "Hipparion" sensu lato at penecontemporaneous earliest Pleistocene localities of Roca-Neyra, Villaroya, Sésklo, and Gülyazi. These localities all have species of Plesiohipparion recognized by us. The penecontemporaneous Italian locality of Montopoli has an "Hipparion" sp., which we believe is referable to ?Cremohipparion by its size and morphology (Rook et al., 2017; this paper). In this regard, new research on the Caucasus area could reinforce the biogeographic linkage between European and Chinese species.

Equus-Hipparion sympatry in Europe is represented by the occurrence of multiple residual lineages of three-toed equids, Plesiohipparion, and possibly Cremohipparion: Plesiohipparion huangheense (Gülyazi, Turkey; Bernor and Lipscomb, 1991), Plesiohipparion cf. P. shanxiense (Sésklo, Greece; Athanassiou, 2018), a possible referral Plesiohipparion rocinantis (Kvabebi, Roca-Neyra, and Villarroya; present paper, pending a complete review of the equid sample of these localities), and the enigmatic record from Montopoli (Italy; Rook et al., 2017; this paper), which could be referred to ?Cremohipparion sp. We have presented evidence that Proboscidipparion is restricted to the Pliocene, represented by the species $P$. heintzi from Çalta, (Turkey) (Bernor and Sen, 2017) and P. crassum from Perpignan (France), Dorkovo (Bulgaria), Suffolk (England) (Alberdi and Alcalà, 1999; present paper), and therefore not recorded as co-occurring with the genus Equus outside China.

In China, Proboscidipparion co-occurs with Equus until 1 Ma (Qiu et al., 1987). In Africa, Eurygnathohippus persists until sometime younger than $1 \mathrm{Ma}$ (Bernor and Armour-Chelu, 1999; Bernor et al., 2010), co-occurring with the genus Equus since its FAD at 2.33 Ma (Eisenmann, 1983; Bernor et al., 2010, 2019; Rook et al., 2019). Clearly, the so-called "Hipparion Last Appearance Datum" was diachronous across Eurasia and Africa, with multiple lineages having become extinct by ca. 1 Ma.

\section{Conclusions}

Our review of the Roca-Neyra equid sample and comparisons with other Eurasian Plio-Pleistocene equid assemblages has led to new insights on the taxonomic diversity of PlioPleistocene "Hipparion" evolutionary lineages and on the Equus FAD in Eurasia. 
As reported in our morphometric and statistical analyses, "Hipparion" crassum from Perpignan (4.1 Ma, Ruscinian, MN15) is referred to the genus Proboscidipparion due its close similarities with the early Pliocene Proboscidipparion heintzi from Çalta (ca. $4 \mathrm{Ma}$ ) in its cranial and postcranial morphology.

The European "Hipparion" samples at the Plio-Pleistocene transition (Kvabebi, Villarroya, and Roca-Neyra) have shown a remarkable resemblance to the late Miocene-Early Pleistocene Plesiohipparion species: P. longipes from Pavlodar and Çalta and $P$. houfenense from Yushe Basin. Furthermore, the Kvabebi, Villarroya, and Roca-Neyra samples may be referred to Plesiohipparion rocinantis due to their morphological similarity. Nevertheless, a revision of the Kvabebi and Villarroya samples would help to clarify the occurrence of multiple Plesiohipparion species in the Plio-Pleistocene Eurasian fossil record.

The Pliocene sample of "Hipparion" fissurae from Layna (3.91, Ruscinian, MN15) remains enigmatic. Its elongateslender metapodial morphology could suggest a referral to either Plesiohipparion or Cremohipparion, and more information from the skull and dentition are needed in order to determinate its generic assignment. Nevertheless, this study has pointed out the possible relationship between the Layna sample and "Hipparion elegans" from Pavlodar, due their close morphological similarities.

The Montopoli fragmentary cheek tooth remains the most obscure "Hipparion." Its size and simplicity of occlusal morphology do not match Plesiohipparion and Proboscidipparion, but, given the latest Miocene occurrence of a small Cremohipparion from Baccinello V3, ?Cremohipparion $\mathrm{sp}$. is a plausible referral.

The Roca-Neyra Equus sample is referred to Equus cf. E. livenzovensis, supported by the occlusal morphology of the lower cheek teeth, which includes intermediate features between the North American Equus simplicidens and the European Equus stenonis. The presence of Equus cf. E. livenzovensis at Roca-Neyra confirms the dispersion of this species at the beginning of the Pleistocene in Europe, and the new age proposed of $2.6 \pm 0.2 \mathrm{Ma}$ (Nomade et al., 2014) correlates this locality with the 2.6 Ma sites of Livensovska, Montopoli, El Rincòn-1, and Huélago, where Equus livenzovensis occurs.

The occurrences of the three-toed equid, here referred to Plesiohipparion cf. P. rocinantis, and the monodactyl horse Equus cf. E. livenzovensis at Roca-Neyra, underscore the importance of this locality in Central and Western Europe, allowing us to recognize it as an important crossroad for the transition from the last European Plio-Pleistocene "Hipparion" sensu lato to the first occurrence of the genus Equus.

\section{Acknowledgments}

We are thankful to E. Robert (Université Claude Bernard-1) and D. Berthet (Museé des Confluences) from Lyon for providing access to OC for studying the Early Pleistocene equids of Central Europe. Furthermore, we thank E. Cioppi and L. Bellucci (Museo di Storia Naturale dell'Univerisità degli Studi di Firenze, sezione di Geologia e Paleontologia) and the Smithsonian Institution for access to the collections in their care. OC thanks the University of Pisa PhD program and University of Florence
(Fondi di Ateneo) for financial support. RLB wishes to acknowledge research funding by NSF EAR grants 8806645,0125009 , 1113175, 1558586; DBI grant 1759882 for the FuTRES database; and support from the Smithsonian Human Origins Program. This is FuTRES publication number 19. Furthermore, we thank V. Eisenmann for her generosity in sharing images and measurements on fossil horses in her public web database, and any other authors who have included available research data. We finally thank M. T. Alberdi and another, anonymous reviewer for their suggestions, which have increased the quality of this manuscript.

\section{Accessibility of supplemental data}

Data available from the Dryad Digital Repository: https://doi. org/10.5061/dryad.hqbzkh1dj.

\section{References}

Abel, O., 1926, Die Geschichte der Equiden auf dem Boden Noramerikas: Verhandlungen Zoologisch-Botanischen Gesellschaft, v. 74, p. 159-164.

Agusti, J., Vekua, A., Oms, O., Lordkipanidze, D., Bukhsianidze, M., Kiladze, G., and Rook, L., 2009, The Pliocene-Pleistocene succession of Kvabebi (Georgia) and the background to the early human occupation of Southern Caucasus: Quaternary Science Review, v. 28, p. 3275-3280.

Alberdi, M.T., 1974, El género Hipparion en España, revision e historia evolutive: Trabajos sobre Neógeno-Cuaternario, v. 1, p. 1-139.

Alberdi, M.T., 1986, The Pliocene species of Hipparion and their biostratigraphical meanings: Geobios, v. 19, p. 517-522.

Alberdi, M.T., 1989, A review of Old World hipparionine horses, in Prothero, D.R., and Schoch, R.M., eds., The Evolution of Perissodactils: New York and London, Oxford University Press, p. 234-261.

Alberdi, M.T., and Alcalà, L., 1999, A study of the new samples of the Pliocene Hipparion (Equidae, Mammalia) from Spain and Bulgaria: Transactions of the Royal Society of Edinburgh: Earth Science, v. 89, p. 167-186.

Alberdi, M.T., Cerdeño, E., López-Martínez, Morales, J., and Soria, M.D., 1997, La fauna Villafranquiense de El Rincón-1 (Albacete, Castilla-La Mancha): Estudios Geologicos, v. 53, p. 69-93.

Alberdi, M.T., Ortiz Jaureguizar, E., and Prado, J.L., 1998, A quantitative review of European stenonoid horses: Journal of Paleontology, v. 72, p. 371-387.

Alexeeva [Alekseeva], L.I., and Garutt, V.E., 1965, Novye dannye ob evolyutsii slonov roda Archidiskodon: Byulleten komissii po lzucheniyu Chetvertichnogo Perioda, AN SSSR, v. 30, p. 161-166. [in Russian]

Arambourg, C., 1959, Vertébrés continentaux du Miocène supérieur de l'Afrique du Nord: Mémoire du Service de la Carte Géologique d'Algérie, Paléontologie, v. 4, p. 1-161.

Athanassiou, A., 2018, A Villafranchian Hipparion-bearing mammal fauna from Sésklo (E. Thessaly, Greece): implications for the question of Hipparion-Equus sympatry in Europe: Quaternary, v. 1, 12. p. 1-24. doi:10.3390/quat 1020012

Aymard, A., 1854, Des Terrains Fossiliferes du Bassin Superior de la Lorire: Comptes Rendus de l'Academia des Science de France, Series D, v. 38 , p. 673-677.

Azanza, B., Morales, M., Andrés, M., Cerdeño, E., and Alberdi, M.T., 2016, Los macromamíferos y la datación del yacimiento clásico de Villarroya, in Alberdi, M.T., Azanza, B., and Cervante, E., eds, Villarroya, Yacimiento Clave de la Paleontologìa Riojana: Instituto de Estudios Riojanos, v. 56, p. $267-280$.

Azzaroli, A., 1964, The two Villafranchian horses of the Upper Valdarno: Palaeontographia Italica, v. 59, p. 1-12.

Azzaroli, A., 1982, On Villafranchian Palaearctic equids and their allies: Palaeontographia Italica, v. 72, p. 74-97.

Azzaroli, A., 1983, Quaternary mammals and the "end-Villafranchian" dispersal event - a turning point in the history of Eurasia: Palaeogeography, Palaeoclimatology, Palaeoecology, v. 44, p. 117-139. doi:10.1016/00310182(83)90008-1.

Azzaroli, A., 1992, Ascent and decline of monodactyl equids: a case for prehistoric overkill: Annales Zoologici Fennici, v. 28, p. 151-163.

Azzaroli, A., 2000, On Equus livenzovensis Bajgusheva, 1978 and the "stenonid" lineage of equids: Palaeontographia Italica, v. 87, p. 1-17.

Azzaroli, A., 2002, Phylogeny of the genus Equus L.: Palaeontographia Italica, v. 84 , p. $11-16$. 
Azzaroli, A., and Voorhies, M.R., 1993, The Genus Equus in North America. The Blancan species: Palaeontographia Italica, v. 80, p. 175-198.

Bajgusheva [Baigusheva], V.S., 1978, Krupnaya loshad Khaprovskogo kompleksa iz allyuviya Severo-vostochnogo Priazoviya: Izvestiya SeveroKavkazkogo Nauchnogo Tsentra Vyschei Shkoly, Estestvennye Nauki, v. 1, p. 98-102. [in Russian]

Bajgusheva, V.S., Titov, V.V., and Tesakov, A.S., 2001, The sequence of PlioPleistocene mammal faunas from south Russian Plain (the Azov Region): Bollettino della Società Paleontologica Italiana, v. 40, p. 133-138.

Barrón-Ortiz, C.I., Avilla, L.S., Jass, C.N., Bravo-Cuevas, V.M., Machado, H. and Mothé, D., 2019, What is Equus? Reconciling taxonomy and phylogenetic analyses: Frontiers in Ecology and Evolution, v. 7, n. 343. doi:10. 3389/fevo.2019.00343.

Bartolini Lucenti, S., 2017, Nyctereutes megamastoides (Canidae, Mammalia) from the early and middle Villafranchian (late Pliocene and Early Pleistocene) of the Lower Valdarno (Firenze and Pisa, Tuscany, Italy): Rivista Italiana di Paleontologia e Stratigrafia, v. 123, p. 211-218.

Berggren, W.A., and Van Couvering, J.A., 1974, The late Neogene: Palaeogeography, Palaeoclimatology, Palaeoecology, v. 16, p. 1-215.

Bernor, R.L., and Armour-Chelu, M., 1999, Towards an evolutionary history of African hipparionine horses, in Bromage, T., and Schrenk, F., eds., African Biogeography, Climate Change and Early Hominid Evolution: New York, Oxford University Press, p. 189-215.

Bernor, R.L., and Harris, J.M., 2003, Systematics and evolutionary biology of the late Miocene and early Pliocene hipparionine horses from Lothagam, Kenya, in Harris, J.M., and Leakey, M.G., eds., Lothagam: The Dawn of Humanity in Eastern Africa: New York, Columbia University Press, p. 387-438.

Bernor, R.L., and Hussain, S.T., 1985, An assessment of the systematic, phylogenetic and biogeographic relationships of Siwalik hipparionine horses: Journal of Vertebrate Paleontology, v. 5, p. 32-87.

Bernor, R.L., and Lipscomb, D., 1991, The systematic position of "Plesiohipparion" aff. huangeense (Equidae, Hipparionini) from Gülyazi, Turkey: Mitteilungen der Bayerischen Staatssammlung für Paläontologie und Historiesche Geologie, v. 31, p. 107-123.

Bernor, R.L., and Sen, S., 2017, The early Pliocene Plesiohipparion and Probiscidipparion (Equidae, Hipparionini) from Çalta, Turkey (Ruscinian Age, c. $4.0 \mathrm{Ma}$ ): Geodiversitas, v. 39, p. 28-41.

Bernor, R.L., and Sun, B.Y., 2015, Morphology through ontogeny of Chinese Proboscidipparion and Plesiohipparion and observations on their Eurasian and African relatives: Vertebrata Palasiatica, v. 53, p. 73-92.

Bernor, R.L., and White, T.D., 2009, Systematics and biogeography of "Cormohipparion" africanum, Early Vallesian (MN 9, ca. 10.5 Ma) of Bou Hanifia, Algeria, in Albright, L.B., III, ed., Papers on Geology, Vertebrate Paleontology, and Biostratigraphy in Honour of Michael O. Woodburne: Museum of North Arizona Bulletin, v. 65, p. 635-658.

Bernor, R.L., Qiu, Z., and Hayek, L.A.C., 1989, Systematic revision of Chinese Hipparion species described by Sfeve, 1927: American Museum Novitates. v. 2984, p. 1-60.

Bernor, R.L., Tobien, H., and Woodburne, M.O., 1990, Patterns of Old Word hipparionine evolutionary diversification and biogeographic dxtension, in Lindsay, E.H., Fahlbusch, V., and Mein, P., eds, European Neogene Mammal Chronology: New York, Plenum Press, p. 263-319.

Bernor, R.L., Koufos, G.D., Woodburne, M.O., and Fortelius, M., 1996, The evolutionary history and biochronology of European and southwestern Asian late Miocene and Pliocene hipparionine horses, in Bernor, R.L., Fahlbusch, V., and Mittman, H.W., eds., The Evolution of Western Eurasian Neogene Mammal Faunas: New York, Columbia University Press, p. 307-338.

Bernor, R.L., Tobien, H., Hayek, L.A.C., and Mittmann, H.W., 1997, Hippotherium primigenium (Equidae, Mammalia) from the late Miocene of Höwenegg (Hegau, Germany): Andrias, v. 10, p. 1-230.

Bernor, R.L., Scott, R. S., Fortelius, M., Kappelman, J., and Sen, S., 2003, Systematics and evolution of the late Miocene hipparions from Sinap, Turkey, in Fortelius, M., Kappelman, J., Sen, S., and Bernor, R.L., eds., The Geology and Paleontology of the Miocene Sinap Formation, Turkey: New York, Columbia University Press, p. 220-281.

Bernor, R.L., Scott, R.S., and Haile-Selassie, Y., 2005, A contribution to the evolutionary history of Ethiopian hipparionine horse: morphometric evidence from postcranial skeleton: Geodiveristas, v. 27, p. 133-158.

Bernor, R.L., Armour-Chelu, M., Gilbert, H., Kaiser, T.M., and Schulz, E., 2010, Equidae, in Werdelin, L., and Sanders, W.J., eds., Cenozoic Mammals of Africa: Berkeley, CA, University of California Press, p. $685-721$

Bernor, R.L., Kaiser, T.M., Nelson, S.V., and Rook, L., 2011, Systematics and paleobiology of Hippotherium malpassi n. sp. from the latest Miocene of Baccinello V3 (Tuscany, Italy): Bollettino della Societa Paleontologica Italiana, v. 50, p. 175-208.

Bernor, R.L., Boaz, N.T., and Rook, L., 2012, Eurygnathohippus feibeli (Perissodacyla: Mammalia) from the late Miocene of As Sahabi (Libya) and its evolutionary and biogeographic significance: Bollettino della Società Paleontologica Italiana, v. 51, p. 39-48.

Bernor R.L., Gilbert, H., Semprebon, G.M., Simpson, S., and Sileshi Semaw, S., 2013, Eurygnathohippus woldegabrieli, sp. nov. (Perissodactyla, Mammalia), from the middle Pliocene of Aramis, Ethiopia: Journal of Vertebrate Paleontology, v. 33, p. 1472-1485. doi:10.1080/02724634.2013.829741.

Bernor, R.L., Sun, B., and Chen, Y., 2015, Plesiohipparion shanxiense n. sp. from the Early Pleistocene (Nihowanian) of E Shanxi, China: Bollettino della Società Paleontologica Italiana, v. 54, p. 197-210.

Bernor, R.L., Ataabadi, M.M., Meshida, K., and Wolf, D., 2016, The Maragheh hipparions, late Miocene of Azarbaijan, Iran: Paleobiodiversity and Palaeoenviroments, v. 96, p. 453-488. doi:10.1007/s12549-016-0235-2.

Bernor, R.L., Göhlich, U.B., Harzhauser, M., and Semprebon, G.M., 2017, The Pannonian $\mathrm{C}$ hipparions from the Vienna basin: Palaeogeography, Palaeoclimatology, Palaeoecology, v. 476, p. 28-41.

Bernor, R.L., Wang. S., Liu, Y., Chen, Y., and Sun, B., 2018a, Shanxihippus dermatorhinus comb. nov. comparisons to Old World hipparions with specialized nasal apparati: Rivista Italiana di Paleontologia e Stratigrafia, v. 124, p. 361-386.

Bernor, R.L., Cirilli, O., Wang, S.Q., and Rook, L., 2018b, Equus cf. livenzovenzis from Montopoli, Italy (Early Pleistocene; MN16b; ca. 2.6 Ma): Bollettino della Socità Paleontologica Italiana, v. 57, p. 203-216. doi:10.4435/ BSPI.2018.13.

Bernor, R.L., Cirilli, O., Jukar, A.M., Potts, R., Bukhsianidze, M., and Rook, L., 2019, Evolution of early Equus in Italy, Georgia, the Indian Subcontinent, East Africa, and the origins of African zebras: Frontiers in Ecology and Evolution, v. 7, n. 166. doi:10.3389/fevo.2019.00166.

Bernor, R.L., Boaz, N., Cirilli, O., El-Shawaihdi, M.H., and Rook, L., 2020, Sahabi Eurygnathohippus feibeli: its systematic, stratigraphic, chronologic and biogeographic contexts: Rivista Italiana di Paleontologia e Stratigrafia, v. 126 , p. 561-581.

Bout, P., 1960, Le Villafranchien du Valey et du Bassin Hydrographique Moyen et Supérieur de l'Allier: Correlations Francaises et Européennes [Ph.D. thesis]: Paris, Université de Paris, Imprimerie Jeanne d'Arc, le Puy, 344 p.

Bravo-Cuevas, V.M., and Jiménez-Hidalgo, E., 2019, Evolutionary significance of Equinae From the Mexican Neogene: Frontiers in Ecology and Evolution, v. 7, n. 287. doi:10.3389/fevo.2019.00287.

Carranza-Castañeda, O., 2019, Dinohippus mexicanus (early-late, late, and latest Hemphillian) and the transition to genus Equus, in Central Mexico faunas: Frontiers in Earth Science, v. 7, n. 89. doi:10.3389/feart.2019. 00089.

Cherin, M., Iurino, D.A., and Sardella, R., 2013, Earliest occurrence of Puma pardoides (Owen, 1846) (Carnivora, Felidae) at the Plio/Pleistocene transition in western Europe: new evidence from the middle Villafranchian assemblage of Montopoli, Italy: Compes Rendus Palevol, v. 12, p. 165-171.

Cirilli, O., Zouhri, S., El Boughabi, S., Benvenuti, M.G., Papini, M., Bernor, R.L., and Rook, L., 2020, The hipparionine horses (Perissodactyla: Mammalia) from the late Miocene of Tizi N'Tadderht (southern Ouarzazate basin; central High Atlas; Morocco): Rivista Italiana di Paleontologia e Stratigrafia, v. 126, p. 1-12.

Cirilli, O., Pandolfi, L., and Bernor, R.L., in press, The Villafranchian perissodactyls of Italy: knowledge of the fossil record and future research perspectives: Geobios. doi:10.1016/j.geobios.2020.09.001.

Clauzon, G., Le Strat, P., Duvail, C., Do Couto, D., Suc, J.P., Molliex, S., Bache, F., Besson, D., Lindsay, E.H., Opdyke, N.D., Rubino, J.L., Popescu, S.M., Haq, B.U., and Gorini, C., 2015, The Roussilon basin (S. France): a casestudy to distinguish local and regional events between 6 and 3 Ma: Marine and Petroleum Geology, v. 66, p. 18-40.

Cocchi, I., 1867, L'uomo fossile dell'Italia Centrale: Memorie della Società Italiana di Scienze Naturali, v. 2, p. 1-180.

Cope, E.D., 1892, A contribution to the vertebrate paleontology of Texas: Proceedings of the American Philosophical Society, v. 30, p. 123-131.

Croizet, J.B., and Jobert, A., 1828, Recherches sur les ossemens fossils du Département du Puy-de-Dôme: Paris, Thibaut-Landriot, 224 p.

Crusafont, P.M., and Sondaar, P., 1971, Una nouvelle espece d'Hipparion du Pliocéne terminal d'Espagne: Palaeovertebrata, v. 4, p. 59-66.

Dawkins, W., 1868, On a new species of deer from the Norwich Crag: Quarterly Journal of the Geological Society of London, v. 24, p. 516-518.

Del Campana, D., 1914, La Lycyaena lunensis n. sp. dell'ossario di Olivola (Val di Magra): Palaeontographia Italica, v. 20, p. 87-104.

Delson, E., Faure, M., Guérin, C., Aprile, L., Argant, J., Blackwell, B.A.B., Debard, E., Harcourt-Smith, W., Martin-Suarez, E., Monguillon, A., Parenti, F., Pastre, J.F., Sen, S., Skinner, A.R., Swisher, C.C., III, and Valli, A.M.F., 2006, Franco-American renewed research at the late Villafranchian locality of Senèze (Haute-Loire, France): Courier Forschungsinstitut Senckenberg, v. 256, p. 275-290.

Deng, T., and Xue X., 1999, Equus qingyangensis sp. nov. (Perissodactyla, Equidae) from the Early Pleistocene of Qingyang, Gansu, China: Vertebrata Palasiatica, v. 37, p. 62-74. 
Depéret, C., 1884, Nouvelles etudes sur les Ruminants Pliocenes et Quaternaires d'Auvergne: Bulletin de la Société Géologique de France, v. 12, p. 247-284.

Depéret, C., 1890, Les animaux pliocènes du Roussilon: Mémoires de la Société Géologique de France, v. 3, p. 1-198.

Devèze de Chabriol, J.S., and Bouillet, J.B., 1827, Essai géologique et minéralogique sur les environs d'Issoire, Département du Puy-de-Dôme, et principalement sur la Montagne de Boulade: avec la description et les figures lithographiées des ossemens fossiles qui y ont eté recueillis: ClermontFerrand, France, Imprimerie de Thibaud-Landriot, 104 p.

Domingo, M.S., Alberdi, M.T., and Azanza, B., 2007, A new quantitative biochronological ordination for the upper Neogene mammalian localities of Spain: Palaeogeography, Palaeoclimatology, Palaeoecology, v. 255 , p. 361-376.

Domingo, L., Koch, P.L., Fernández, M.H., Fox, D.L., Domingo, M.S., and Alberdi, M.T., 2013, Late Neogene and early Quaternary paleoenvironmental and paleoclimatic conditions in southwestern Europe: isotopic analyses on mammalian taxa: PLoS One, v. 8, n. 63739. doi.org/10.1371/ journal.pone.0063739.

Eisenmann, V., 1976, Nouveaux crânes d'hipparions (Mammalia, Perissodactyla) Plio-Pleistocènes d'Afrique orientale (Ethiopie et Kenya): Hipparion sp., Hipparion cf. ethiopicum et Hipparion afarense nov. sp: Géobios, v. 5, p. 577-605.

Eisenmann, V., 1983, Family Equidae, in Harris, J.M., ed., Koobi Fora Research Project Volume 2, The Fossil Ungulates: Proboscidea, Perissodactyla and Suidae: Oxford, UK, Clarendon Press, p. 156-214.

Eisenmann, V., 1995, What metapodial morphometry has to say about some Miocene hipparions, in Vrba, E.S., Denton, G.H., Partridge, T.C., and Burckle L.H., eds., Paleoclimate and Evolution: With Emphasis on Human Origins: New Haven, CT, Yale University Press, p. 148-163.

Eisenmann, V., 2019, Website, https://vera-eisenmann.com

Eisenmann, V., and Brunet, J., 1973, Présence simultanée de cheval et d'Hipparion dans le Villafranchian moyen de France, à Roccaneyra (Puy-de-Dôme); Etude critique de cas semblables (Europe et Proche-Orient): International Colloqium on the Problem: "The Boundary between Neogene and Quaternary," Moscow, Collection of papers IV, p. $104-122$.

Eisenmann, V., and Sondaar, P., 1998, Pliocene vertebrate locality of Calta, Ankara, Turkey. Hipparion: Geodiversitas, v. 20, p. 409-439.

Eisenmann, V., and Baylac, M., 2000, Extant and fossil Equus (Mammalia, Perissodactyla) skulls: a morphometric definition of the genus Equus: Zoologica Scripta, v. 29, p. 89-100.

Eisenmann, V., and Deng, T., 2005, Equus qingyangensis (Equidae, Perissodactyla) of the upper Pliocne of Bajiazui, China: evidence for North American origin of an Old World lineage distinct from E. stenonis: Quaternaire, v. 2, p. 113-122.

Eisenmann, V., and Geraads, D., 2007, Hipparion pomeli sp. nov from the late Pliocene of Ahl al Oughlam, Morocco, and a revision of the relationships of Pliocene and Pleistocene African hipparions: Palaeontologia Africana, v. 42, p. 51-98.

Eisenmann, V., Alberdi, M.T., De Giuli, C., and Staesche, U., 1988, Methodology, in Woodburne, M., and Sondaar, P.Y., eds., Studying Fossil Horses: Leiden, The Netherlands, EJ Brill Press, p. 1-71.

Falconer, H., 1868, Palaeontological Memoirs of the Late Hugh Falconer, A.M., M.D., with a Biographical Sketch of the Author. Vol. II, Mastodon, Elephat, Rinoceros, Ossiferous Caves, Primeval Man and His Contemporaries: London, Robert Hardwicke, 860 p.

Forsten, A., 1968, Revision of the Palearctic Hipparion: Acta Zoologica Fennica, v. 119, p. 1-134.

Forsten, A., 1998, The fossil horses (Equidae, Mammalia) from the PlioPleistocene of Liventsovka near Rostov-Don, Russia: Geobios, v. 31, p. $645-657$.

Forsten, A., 2001, The hipparions (Mammalia, Equidae) of Suffolk, England: Transactions of the Royal Society of Edinburgh: Earth Science, v. 92, p. $115-120$.

Forsten, A., 2002, Latest Hipparion Cristol, 1832 in Europe. A review of the Pliocene Hipparion crassum Gervais Group and other finds (Mammalia, Equidae): Geodiversitas, v. 24, p. 465-486.

Gervais, P., 1859, Zoologie et Paléontologie Française (Animaux Vertébrés): deuxième edition: Paris, Arthus Bertrand, 544 p.

Gray, H., 1821, On the natural arrangement of vertebrose animals: London Medical Repository Review, v. 15, p. 296-310.

Gromova, V., 1952, The Genus Hipparion: Trudy Paleontologie Institut, v. 36, 478 p. [in Russian]

Guérin, C., 1972, Une nouvelle espèce de rhinocéros, Mammalia, Perissodactyla) à Vialette, Haute-Loire, France) et dans d'autres gisements du Villafranchien Inférieur européen: Dicerorhinus jeanvireti n. sp: Documents des Laboratoires de Géologie de la Faculté des Sciences de Lyon, v. 49, p. 53-161.
Guérin, C., 1990, Biozones or Mammal Units? Methods and limits in biochronology, in Lindsay E.H., Fahlbusch V., and Mein P., eds, European Neogene mammal chronology: New York, Plenum Press, p. 119-130.

Hays, I., 1834, Descriptions of the specimens of inferior maxillary bones of Mastodons in the cabinet of the American Philosophical Society, with remarks on the genus Tetracaulodon (Godman): Transactions of the American Philosophical Society, v. 4, p. 317-339.

Heintz, E., 1970, Les Cervides Villafranchiens de France et d'Espagne: Memoires du Museum national d'histoire naturelle, Series C, v. 22, p. 1-302.

Hernández-Pacheco, E., 1921, La llanura manchega y sus mamíferos fósiles: yacimiento de La Puebla de Almoradier: Comisión de Investigaciones Pleontológicas y Prehistóricas, Memoria, v. 28, p. 1-41.

Hooijer, D.A., and Maglio, V.J., 1974, Hipparions from the late Miocene and Pliocene of Northwestern Kenya: Zoologische Verhandelingen, v. 134, p. 1-34

Jukar, A., Sun, B., and Bernor, R.L., 2018, The first occurrence of Plesiohipparion huangheense (Qiu, Huang \& Guo, 1987) (Equidae, Hipparionini) from the late Pliocene of India: Bollettino della Società Paleontologica Italiana, v. 57, p. 125-132.

Jukar, A.M., Sun, B., Nanda, A.K., and Bernor, R.L., 2019, The first occurrence of Eurygnathohippus (Mammalia, Perissodatyla, Equidae) outside Africa and its biogeographic significance: Bollettino della Società Paleontologica Italiana, v. 58, p. 171-179.

Koufos, G.D., 1986, Study of the Vallesian hipparions of the lower Axios Valley (Macedonia, Greece): Geobios, v. 19, p. 61-79.

Koufos, G.D., and Vlachou, T., 2005, Equidae (Mammalia, Perissodactyla) from the late Miocene of Akkaşdağı, Turkey: Geodiversitas, v. 27, p. 633-705.

Kurten, B., 1963, Villafranchian faunal evolution: Commentationes Biologicae, Societatis Scientiarium Fennica, v. 26, p. 1-18.

Lindsay, E.H., Opdyke, N.D., and Johnson, N.M., 1980, Pliocene dispersal of the horse Equus and late Cenozoic mammal dispersal events: Nature, v. 287, p. 135-138. doi:10.1038/287135a0.

Linnaeus, C., 1758, Systema naturae per regna tria naturae, secundum Classes, Ordines, Genera, Species cum characteribus, differentiis, synonimis, locis: Editio decima, reformata. Stockholm, Laurentii Salvii, 824 p.

López-Martínez, N., 1989, Revisión sistemática y biostratigráfica de los Lagomorpha (Mammalia) del Terciario y Cuaternario de España: Memorias del Museo Paleontologico de la Universidad de Zaragoza, v. 3, p. 5-343.

MacFadden, B.J., 1984, Systematics and phylogeny of Hipparion, Neohipparion, Nannippus and Cormohipparion (Mammalia, Equidae) from the Miocene and Pliocene of the New World: Bulletin of the American Museum of Natural History, v. 179, p. 1-195.

Mein, P., 1999, European Miocene mammal biochronology, in Rössner, G.E., and Heissig, K., eds, The Miocene Land Mammals of Europe: München, Verlag Dr. Friedrich Pfeil, p. 25-38.

Nomade, S., Pastre, J.F., Guillou, H., Faure, M., Guérin, C., Delson, E., Debard, E., Voinchet, P., and Messager, E., 2014, ${ }^{40} \mathrm{Ar} /{ }^{39} \mathrm{Ar}$ constraints on some French landmark late Pliocene to Early Pleistocene large mammalian paleofaunas: paleoenvironmental and paleoecological implications: Quaternary Geochronology, v. 21, p. 2-15. doi:10.1016/j.quageo.2012.12.006.

Oustalet, E., 1882, Une nouvelle espèce de zèbre, le zèbre de Grévy (Equus grevyi): La Nature, v. 10, p. 12-14.

Owen, R., 1846, A History of British Fossil Mammals, and Birds: London, John Van Voorst, $560 \mathrm{p}$.

Owen, R., 1848, Description of the teeth and portions of jaws of two extinct anthracotheroid quadrupeds (Hyopotamus vectianus and Hyop. bovinus) discovered by the Marchioness of Hastings in the Eocene deposits of the N.W. coast of the Isle of Wight: with an attempt to develop Cuvier's idea of the classification of Pachyderms by the number of their toes: Quarterly Journal Geological Society of London, v. 4, p. 103-141.

Palombo, M.R., and Valli A.M.F., 2004, Remarks on the biochronology of mammalian faunal complexes from the Pliocene to the Middle Pleistocene in France: Geologica Romana, v. 37, p. 145-163.

Palombo, M.R., and Alberdi, M.T., 2017, Light and shadows in the evolution of South European stenonoid horses: Fossil Imprint, v. 73, p. 115-140.

Palombo, M.R., Alberdi, M.T., Bellucci, L., and Sardella, R., 2017, An intriguing middle-sized horse from Coste San Giacomo (Anagni Basin, central Italy): Quaternary Research, v. 87, p. 347-362.

Pandolfi, L., 2013, New and revised occurrences of Dihoplus megarhinus (Mammalia Rhinocerotidae) in the Pliocene of Italy: Swiss Journal of Palaeontology, v. 132, p. 239-255.

Pandolfi, L., Cerdeño, E., Codrea, V., and Kotsakis, T., 2017, Biogeography and chronology of the Eurasian extinct rhinoceros Stephanorhinus etruscus, Mammalia, Rhinocerotidae: Comptes Rendus Palevol, v. 16, p. 762-773.

Pandolfi, L., Popuscu, A., and Codrea, V., 2019, Stephanorhinus jeanvireti (Mammalia, Rhinocerotidae) from the Early Pleistocene of Coltesti, southwestern Romania: Comptes Rendus Palevol, v. 18, p. 1041-1056.

Pastre, J.F., 2004, The Perrier Plateau: a Plio-Pleistocene long fluvial record in the river Allier basin, Massif Central, France: Quaternaire, v. 15, p. 87-102. 
Pilgrim, G.E., 1910, Notices of new mammalian genera and species from the Tertiaries of India: Records of the Geological Survey of India, v. 40, p. 63-71.

Pirlot, P.R., 1956, Les formes européennes du genre Hipparion: Memorias y comunicaciones del Instituto Geológico, Diputación Provincial de Barcelona, v. 14, p. 1-122.

Pomel, M., 1842, Nouvelle espèce de chien fossile découverte dans les alluvions volcaniques de l'Auvergne: Bulletin de la Societé géologique de France, v. 14, p. 38-41.

Pomel, A., 1853, Catalogue méthodique et descriptif des vertébrés fossiles découverts dans le bassin hydrographique supérieur de la Loire, et surtout dans la vallée de son affluent principal l'Allier: Paris, J.B. Ballière, $193 \mathrm{p}$.

Prat, F., 1964, Contribution a la classification des Equidés Villafranchiens: Procès Verbaux de la Socíété Linnéenne de Bordeaux, v. 101, p. 14-32.

Pueyo, E.L., Muñoz, A., Laplana, C., and Parés, J.M., 2016, The last appearance datum of Hipparion in Western Europe: magnetostratigraphy along the Pliocene-Pleistocene boundary in the Villarroya basin (northern Spain): International Journal of Earth Science, v. 105, p. 2203-2220.

Qiu, Z., Huang, W., and Guo, Z., 1987, The Chinese hipparionine fossils: Palaeontologia Sinica, New series C, v. 17, p. 1-250.

Qiu, Z.X., Deng T., and Wang, B.Y., 2004, Early Pleistocene mammalian fauna from Longdan, Dongxiang, Gansu, China: Palaeontologia Sinica, New Series C, v. 27, p. 162-164.

Quinn, J.H., 1955, Miocene Equidae of the Texas Gulf Coastal Plain: Bureau of Economic Geology, The University of Texas Report of Investigations, v. 5516 , p. $1-102$

R Core Team, 2013, R: a language and environment for statistical computing. R Foundation for Statistical Computing, Vienna, Austria, ISBN 3-900051-07-0. http://www.R-project.org/

Radulescu, C., and Samson, P., 1967, Sur la signifaction de certains Equidés du Plèistocéne inférieur et moyen de Roumanie: Neues Jahrbuch für Geologie und Paläontologie Abhandlungen, v. 127, p. 157-178.

Rook, L., and Martínez-Navarro, B., 2010, Villafranchian: the long story of a Plio-Pleistocene European large mammal biochronologic unit: Quaternary International, v. 219, p. 134-144.

Rook, L., Cirilli, O., and Bernor, R.L., 2017, A late occurring "Hipparion" from the middle Villafranchian of Montopoli, Italy (Early Pleistocene; MN16b; ca. $2.5 \mathrm{Ma}$ ): Bollettino della Società Paleontologica Italiana, v. 56, p. 333-339.

Rook, L., Bernor, R.L., Avilla, L.D., Cirilli, O., Flynn, L., Jukar, A.M., Sanders, W., Scott, E., and Wang, X., 2019, Mammal biochronology (Land Mammal Ages) around the world from the late Miocene to Middle Pleistocene and major events in horse evolutionary history: Frontiers in Ecology and Evolution, v. 7, n. 278. doi:10.3389/fevo.2019.00278.

Roth, J., and Wagner, A., 1855, Die fissilen Knochenüberreste von Pikermi: Bayerischen Akademie Wisseenschaften, Abhandlungen, v. 7, p. 361-464.

Schaub, S., 1923, Neue und wenig bekannte Cavicornier von Seneze: Eclogae Geologicae Helvetiae, v. 18, p. 281-295.
Schaub, S., 1944, Die oberpliocäne Säugetierfauna von Senèze (Haute Loire) und ihre verbreitungsgeschichtliche Stellung: Eclogae Geologicae Helveticae, v. 36, p. 270-289.

Sefve, I., 1927, Die Hipparionen Nord-Chinas: Palaeontologia Sinica, series C, v. 4 , p. $1-54$

Sesé, C., 2006, Los roedores y lagomorfos del Neógeno de España: Estudios Geológicos, v. 62, p. 429-480.

Stehlin, H.G., 1904, Une faune à Hipparion à Perrier: Bulletin de la Société Géologique de France, v. 28, p. 432-444.

Sun, B., and Deng, T., 2019, The Equus datum and the early radiation of Equus in China: Frontiers in Ecology and Evolution, v. 7, n. 429. doi:10.3389/fevo. 2019.00429.

Sun, B., Zhang, X., Liu, Y., and Bernor, R.L., 2018, Sivalhippus ptychodus and Sivalhippus platyodus (Perissodactyla, Mammalia) from the late Miocene of China: Rivista Italiana di Paleontologia e Stratigrafia, v. 124, p. 1-22.

Team QD, 2016, QGIS geographic information system: Open source geospatial foundation project. https://qgis.org.

Teilhard de Chardin, P., and Piveteau, J., 1930, Les mammifères fossiles de fossiles de Nihowan (Chine): Annales de Paleontologie, v. 19, p. 87-119.

Teilhard de Chardin, P., and Young, C., 1931, Fossil mammals from late Cenozoic of northern China: Paleontologica Sinica, Serie C, v. 9, p. 1-67.

Van Hoepen, E.C.N., 1930, Fossiele Pferde van Cornelia: Paleontologiese Navorsing van die Nasionale Museum, Bloemfontein, v. 2, p. 13-24.

Vekua, A., 1972, Kvabebi fauna of Akchagylian Vertebrates: Moscow, Nauka, p. 96-112. [in Russian]

Villalta, J.F., 1948, Una nueva especie de Hipparion en el Villafranquiense: Museo de la Ciudad de Sabadell, v. 4, p. 5-14.

Villalta, J.F., 1952, Contribución al conocimiento de la fauna de mamíferos fósiles del Plioceno de Villarroya (Logroño): Boletín del Instituto Geológico y Minero de España, v. 64, p. 1-201.

von Meyer, H., 1829, Taschenbuch für die gesamte Mineralogie: Zeitschrift für Mineralogie, Neue Folge, v. 23, p. 150-152.

Wolf, D., Bernor, R.L., and Hussain, S.T., 2013, A systematic, biostratigraphic, and paleobiogeographic reevaluation of the Siwalik hipparionine horse assemblage from the Potwar Plateau, Northern Pakistan: Palaeontographica Abteilung A, v. 300, p. 1-115.

Woodburne, M., and Bernor, R.L., 1980, On superspecific groups of some Old World hipparionine horses: Journal of Paleontology, v. 54, p. 1319-1348.

Wüst, E., 1900, Untersuchungen über das Pliozän und das Älteste Pleistozän Thüringens, nördlich vom Thüringer Walde und westlich von der Saale: Abhandlungen der Naturforschenden Gesellschaft zu Halle, v. 23, p. 1-352.

Zhegallo, V.I., 1978, The hipparions of Central Asia: Trudy Soviet Mongolian Palaeontological Expedition, v. 7, p. 1-152.

Zouhri, S., and Bensalmia, A., 2005, Révision systématique des Hipparion sensu lato (Peryssodactyla, Equidae) de l'Ancient Monde: Estudios Geologicos, v. 61, p. 61-99.

Accepted: 15 October 2020 